Teologia i Moralność, volumen 16(2021), numer 2(30)

doi: 10.14746/TIM.2021.30.2.4

ORCID: 0000-0002-1421-5411

MIKOŁAJ GĘBKA

Uniwersytet im. Adama Mickiewicza w Poznaniu

Wydział Teologiczny

\title{
Wokół początku i końca ludzkiego życia. Refleksja nad stosunkiem Polaków do wybranych kwestii bioetycznych z zakresu nauczania Kościoła katolickiego w świetle badań opinii społecznej
}

\section{Wprowadzenie}

W badaniach opinii społecznej podejmowana jest zróżnicowana problematyka - można tu wymienić chociażby preferencje polityczne społeczeństwa, oceny sytuacji (np. społeczno-gospodarczej), oceny polityków oraz różnego rodzaju instytucji, kwestię zadowolenia z życia, wreszcie problemy bieżące, które w danym momencie wywołują szczególny oddźwięk społeczny (ostatnio związane z pandemią COVID-19, a w tym np. z edukacją zdalną) itd. W ramach tej szerokiej problematyki badawczej pojawiają się od czasu do czasu również kwestie etyczne, związane z oceną dopuszczalności określonych zjawisk, zdarzeń czy czynów. W tej kategorii mieszczą się również zagadnienia dotyczące newralgicznych momentów ludzkiego życia - jego początku i końca.

Celem niniejszego opracowania był przede wszystkim przegląd wyników badań opinii społecznej ${ }^{1}$ przeprowadzonych $\mathrm{w}$ okresie ostatnich kilkudziesięciu lat, a dotyczących wybranych kwestii związanych z początkiem i końcem życia. Można przywoływać mniej lub bardziej rozbudowane listy takich problemów, jednakże w dalszej części tekstu uwaga autora została ograniczona do czterech zagadnień, które $\mathrm{z}$ większą częstotliwością ujmowane były w ba-

\footnotetext{
${ }^{1}$ Zakup części pełnych raportów $\mathrm{z}$ badań został sfinansowany ze środków na utrzymanie potencjału badawczego (statutowa) - projekt S/P-B063.
} 
daniach dwóch ośrodków badawczych w Polsce (głównie CBOS, ale także OBOP i jego następców), a mianowicie: aborcji, sztucznego zapłodnienia (in vitro), antykoncepcji i eutanazji, z których każde mogłoby stanowić przedmiot osobnego opracowania ${ }^{2}$. Na zakończenie przedstawiono kilka wniosków płynących z zaprezentowanych wyników badań. Pomimo, że refleksje te były już wcześniej artykułowane, to w obliczu wspomnianych wyników i możliwych kierunków przemian opinii społecznej w zakresie przywołanych zjawisk, należy je potraktować jako ważne kwestie do dalszej dyskusji i poszukiwań badawczych.

Każdy ze wspomnianych problemów jest na swój sposób zjawiskiem złożonym, wieloaspektowym. Możliwy jest ich ogląd np. pod kątem prawnej dopuszczalności (niektóre są obecnie w Polsce całkowicie zakazane, inne są przez prawo dopuszczane/zakazywane w określonym zakresie, jeszcze inne są z punktu widzenia prawa obojętne. W przypadku aborcji zróżnicowane mogą być chociażby przesłanki jej dokonywania, dozwolone bądź zakazane przez prawo; w przypadku sztucznego zapłodnienia można z kolei różnicować grupę, która uczestniczy w procedurze (inaczej mówiąc - dla kogo jest ona dopuszczalna, a dla kogo nie). Można na wspomniane kwestie spojrzeć również pod kątem ich zakresu pojęciowego - jak np. jest to w przypadku eutanazji - jakie zdarzenia lub czyny są albo były włączane w jej obręb bądź z niego wyłączane (np. eutanazja a zakończenie uporczywej terapii) (por. np. Rabiega 2006; Machinek 2011; Zawadka i Balicki 2015).

Przywołane problemy są poddawane ocenie moralnej przez naukę Kościoła katolickiego, który w licznych dokumentach uznaje je za niedopuszczalne, czy to określając je jako zbrodnie przeciwko życiu, które w dzisiejszym świecie „tracą stopniowo charakter «przestępstwa» i w paradoksalny sposób zyskują status "prawa»" (Jan Paweł II 1995, 11) (eutanazja, aborcja), czy wskazując na zagrożenie nierozerwalności prokreacyjnego i więziotwórczego charakteru aktu małżeńskiego (antykoncepcja, in vitro) (por. Sobór Watykański II 1965; Paweł VI 1968; Kongregacja Nauki Wiary 1974; 1980; 1987; Jan Paweł II 1981; 1994; 1995; Franciszek 2016). Ze względu na charakter niniejszego opracowania nie było tutaj możliwości przeprowadzenia szczegółowych analiz poszczególnych kwestii, trzeba jednak pamiętać, że każda z nich - jako przedmiot wspomnianej oceny - jest zjawiskiem skomplikowanym, zniuansowanym (jak chociażby w sytuacji, kiedy życie bądź zdrowie matki ratowane jest kosztem życia dziecka, gdzie śmierć dziecka jest jedynie skutkiem ubocznym, a nie pierwotnym), niemniej, jako punkt odniesienia dla dalszej analizy opinii Polaków wyrażanych w badaniach opinii społecznej przyjęto, że Kościół, uznając świętość życia od poczęcia do naturalnej śmierci, zasadniczo

\footnotetext{
${ }^{2}$ W przypadku aborcji - por. np. Gębka 2018.
} 
ich nie dopuszcza (nawet jeśli jest to do pewnego stopnia uproszczone twierdzenie).

\section{Uwagi metodologiczne}

W analizie został uwypuklony sposób oceniania dopuszczalności poszczególnych zjawisk bądź ich węższych aspektów przez: 1) ogół respondentów; 2) osoby deklarujące praktyki religijne raz w tygodniu oraz 3) osoby deklarujące praktyki religijne częściej niż raz w tygodniu (osoby deklarujące praktyki nieregularne, sporadyczne czy w ogóle niepraktykujące nie były tutaj brane pod uwagę). Jakkolwiek w badaniach nie zostały wyodrębnione poszczególne wyznania chrześcijańskie czy różne religie w ogóle, to ze względu na strukturę religijną Polski ${ }^{3}$ i charakter badań (próba ogólnopolska) przyjęto, w pewnym uproszczeniu, że kiedy mowa była o praktykach religijnych, to chodziło o praktyki rzymskokatolickie. Deklarację praktyk można uznać za swego rodzaju wskaźnik religijności (por. np. CBOS 2010b, 4). Osoby deklarujące praktyki przynajmniej raz $\mathrm{w}$ tygodniu można potraktować jako religijne, w przynajmniej przeciętnym stopniu (wywiązujące się z obowiązku uczestnictwa w niedzielnej mszy - zostały dalej nazwane przeciętnie religijnymi; przez CBOS zostały uznane za trzon Kościoła (por. CBOS 2015a)), natomiast osoby deklarujące praktyki religijne częściej niż raz w tygodniu (wykraczające poza obowiązek mszy niedzielnej) - określono dalej jako bardziej religijne.

Przed zaprezentowaniem i omówieniem wyników badań, trzeba zwrócić uwagę na kilka kwestii metodologicznych:

- badanie opinii społecznej można uznać za swego rodzaju „fotografię” rzeczywistości społecznej w danym momencie - ale taka „fotografia” czasem może być zniekształcona, dlatego bardziej adekwatnym, dającym pełniejszy obraz zjawiska, jest zestawienie kilku „fotografii” (wyników różnych badań); trzeba jednak zaznaczyć, że analizowane tutaj badania nie były prowadzone regularnie, w związku z czym odstęp między nimi był zróżnicowany - od kilku miesięcy do kilku lat;

- zestawy pytań nie były w poszczególnych badaniach jednakowe (nie każda kwestia szczegółowa pojawiała się w każdym badaniu dotyczącym danego zjawiska), dlatego zbiory badań użyte w przypadku analizy poszczególnych zagadnień szczegółowych danego zjawiska nie były identyczne;

\footnotetext{
${ }^{3}$ Według KAI 91,9\% Polaków deklaruje przynależność do Kościoła katolickiego (Kościót w Polsce 2021), w latach wcześniejszych odsetek ten był wyższy - w roku 2005 było to np. 95\% (CBOS 2005c).
} 
czasem też określone problemy były w części badań ujmowane łącznie $\mathrm{w}$ jednym pytaniu, $\mathrm{z}$ kolei $\mathrm{w}$ innych były rozdzielone na odrębne pytania;

- pewien problem stanowiła swoista wybiórczość prezentacji danych w raportach (np. podawano odpowiedzi pokazujące aprobatę dla danego zjawiska, ale pozostałe odpowiedzi były pomijane) czy w tabelach aneksowych (wyniki dotyczące niektórych kwestii były dostępne w rozbiciu na różne kategorie respondentów (np. płeć czy wiek), w przypadku innych - dostępne były tylko wyniki dla ogółu respondentów);

- ze względu na fakt, że w wybranych raportach przedstawione były wyłącznie wyniki pokazujące ogólnie akceptację bądź odrzucenie danego zjawiska, w przypadku innych raportów, gdzie odpowiedzi pokazujące odpowiednio akceptację lub odrzucenie rozbite zostały jeszcze na odpowiedzi silniejsze i słabsze (np. „zdecydowanie tak” i ,raczej tak”), w niniejszym opracowaniu ujęto je łącznie;

- w prezentacji opinii ogółu respondentów przedstawione zostały na wykresach odpowiedzi wskazujące na aprobatę danego zjawiska (co można uznać za opinie sprzeczne z nauczaniem Kościoła), dezaprobatę danego zjawiska (co można uznać z kolei za opinie zgodne z nauczaniem Kościoła) oraz odpowiedzi, które nie zdradzały stanowiska respondenta (np. „trudno powiedzieć"); w przypadku porównań odpowiedzi ogółu respondentów oraz respondentów przeciętnie i bardziej religijnych zostały porównane odpowiedzi pokazujące aprobatę w stosunku do analizowanych zjawisk (a więc stojące w opozycji do nauczania Kościoła); takie podejście było uzasadnione między innymi faktem, że w raportach najpełniejsze dane dotyczyły właśnie aprobaty (inne odpowiedzi były niekiedy pomijane);

- daty na wykresach były na ogół datami publikacji raportu, a nie samych badań, które mogły pochodzić z miesiąca poprzedzającego publikację, jednakże gdy wyniki jednego badania były zawarte w raporcie z któregoś z następnych badań, wówczas podano datę samego badania.

Niezależnie od powyższych uwag i zastrzeżeń dostępne w raportach dane pozwoliły uchwycić kształtujące się na przestrzeni kilkudziesięciu już lat stanowisko Polaków w odniesieniu do aborcji, sztucznego zapłodnienia, antykoncepcji i eutanazji.

\section{Przegląd badań opinii społecznej}

\subsection{Aborcja}

Z przywołanych kwestii bioetycznych w badaniach opinii społecznej najczęściej pojawiała się aborcja, jednakże ze względu na sposób zadawania py- 
tań do analizy porównawczej posłużyły wyniki zawarte tylko w części raportów ${ }^{4}$. Dodatkowo w przypadku tego zjawiska analizę podzielono ze względu na różne przesłanki jej dokonywania.

Rozpoczynając prezentację od przesłanek, których polskie prawo nie dopuszcza - a więc w sytuacji, kiedy kobieta nie chce mieć dzieci (co można w zasadzie uznać za odpowiednik pytania o dopuszczalność aborcji „na życzenie") oraz w sytuacji, kiedy przyczyną aborcji jest trudna sytuacja materialna lub osobista kobiety, można zauważyć, że:

- w pierwszym przypadku (wykres 1) zdecydowana większość respondentów była przeciwna (najwięcej w maju i październiku 2016 r. - 78\%), choć w ostatnich badaniach zauważalny był nieznaczny spadek dezaprobaty;

- w przypadku sytuacji materialnej oraz osobistej (tu przykład łącznego i rozdzielnego ujmowania wybranych kwestii w badaniach, wykres 2) wyraźnie dało się zauważyć, że o ile w latach 90. przeważali zwolennicy dopuszczalności aborcji, o tyle w wieku XXI wystąpił bardzo wyraźny wzrost odsetka opinii przeciwnych dopuszczalności aborcji z tych przesłanek (najwięcej w maju 2016 r. - 80\% w przypadku sytuacji osobistej i 77\% w przypadku sytuacji materialnej), choć w ostatnich badaniach znów widoczny był ich spadek.

Można przypuszczać, że w obu przypadkach prawdopodobnie zauważalne jest odwrócenie obserwowanej dotychczas tendencji wzrostowej, jeśli chodzi o dezaprobatę wobec aborcji.

Z rezerwą należy podchodzić do wyników badań z roku 2006, które - jak zauważył CBOS - mogły zostać zniekształcone przez fakt, że część wywiadów badania podjętego w kontekście próby wprowadzenia zapisu o ochronie życia do konstytucji została przeprowadzona po opublikowaniu apelu abp. Józefa Michalika do parlamentarzystów o wprowadzenie takiego zapisu. Mogło to spowodować nieszczerość respondentów odpowiadających później, a obawiających się wyrażenia opinii niezgodnej ze stanowiskiem Kościoła (por. CBOS 2006; Gębka 2018). W roku 2016 zdarzyła się podobna sytuacja, kiedy podczas realizacji badań odczytany został w kościołach list Prezydium Konferencji Episkopatu Polski w sprawie aborcji, lecz w tym przypadku zdaniem CBOS zasadniczo nie wpłynęło to na wyniki (CBOS 2016a), dlatego można sądzić, że obecnie - gdyby doszło znów do podobnej sytuacji - to odchylenie zbliżone do tego z roku 2006 nie byłoby zauważalne.

\footnotetext{
${ }^{4}$ Aborcja była przedmiotem analiz w przynajmniej 50 badaniach przeprowadzonych w latach 1989-2020 przez 2 ośrodki badawcze: CBOS i OBOP (lub jego następców). W analizach wykorzystano wyniki z 21 raportów z lat 1992-2020. Zestawienie raportów w tabeli $1 \mathrm{w}$ aneksie. O stosunku ogółu respondentów do aborcji - por. Gębka 2018; w obecnych analizach zostały dodane najnowsze wyniki badań z roku 2020.
} 


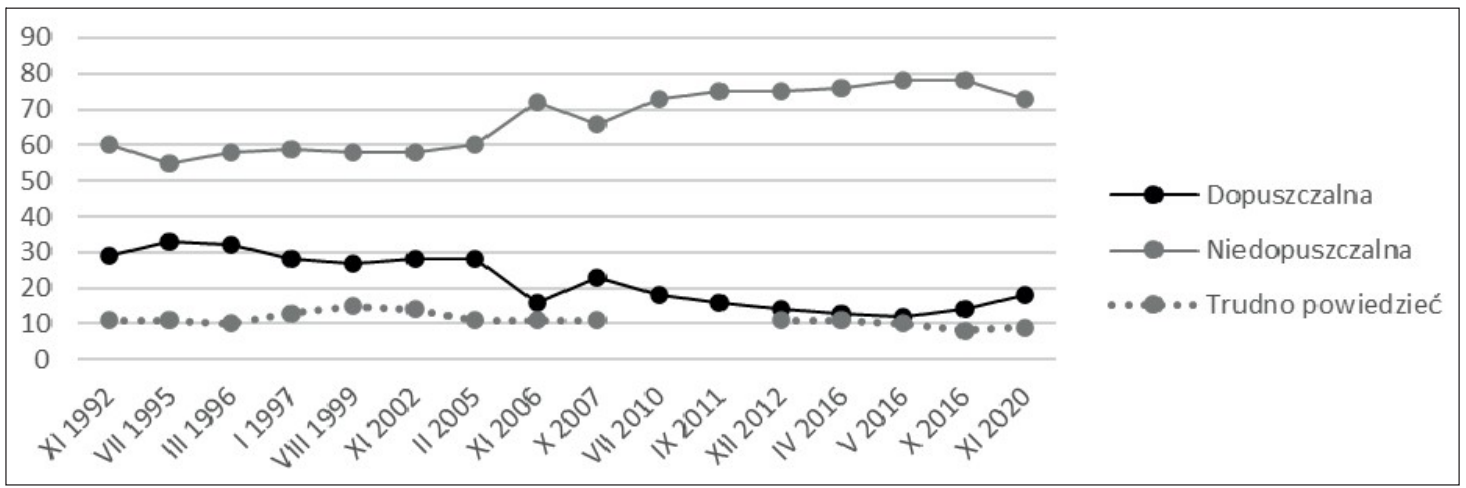

Wykres 1. Dopuszczalność aborcji w sytuacji, kiedy kobieta nie chce mieć dzieci (w procentach $)^{5}$

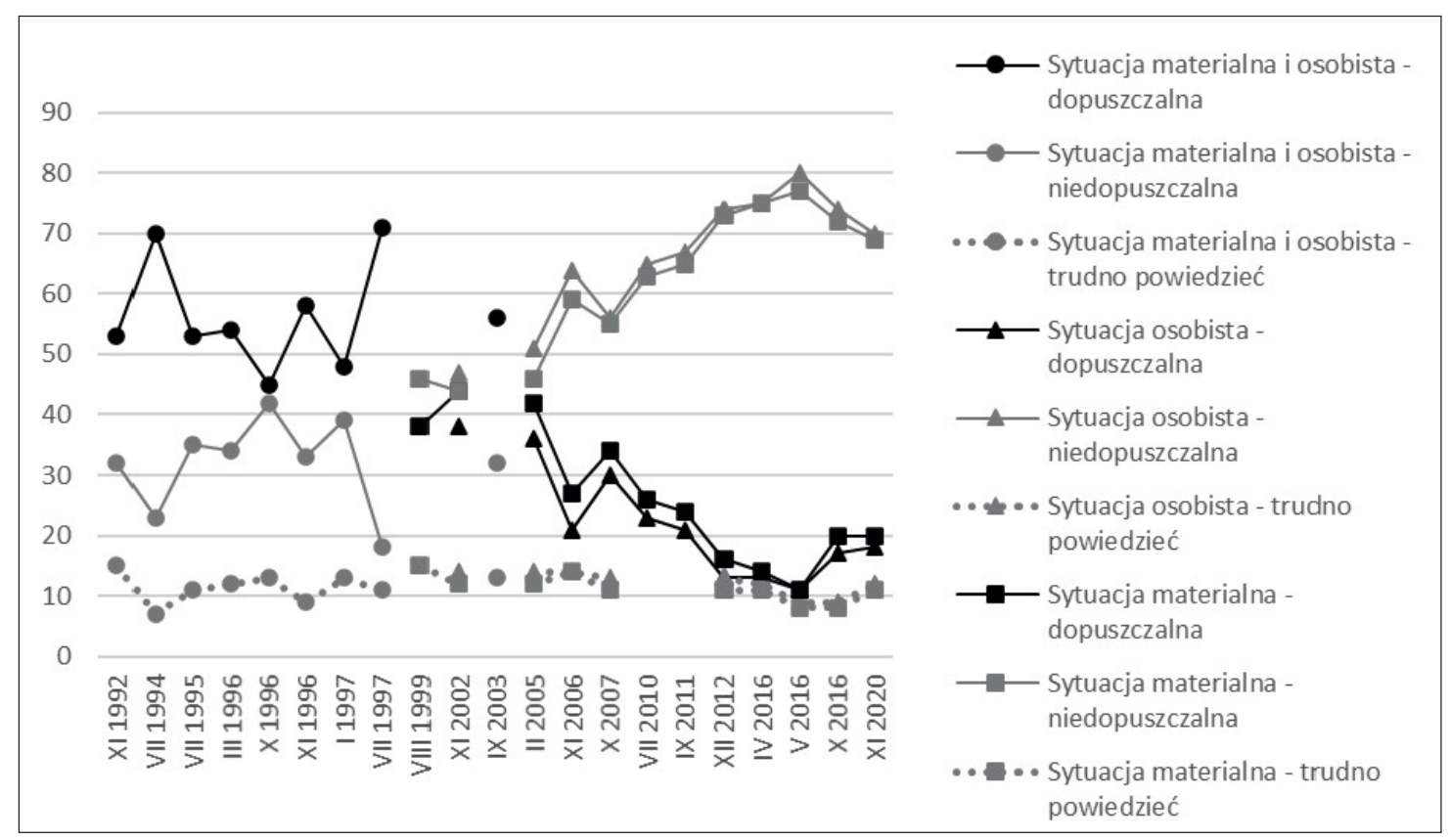

Wykres 2. Dopuszczalność aborcji ze względu na trudną sytuację materialną lub osobistą kobiety (w procentach)

Przechodząc do przesłanek aborcji, które dopuszcza (lub do 2020 r. dopuszczała) Ustawa z dnia 7 stycznia 1993 r. o planowaniu rodziny, ochronie płodu ludzkiego i warunkach dopuszczalności przerywania ciąży (1993),

${ }^{5}$ Prezentowane w opracowaniu wykresy stanowią opracowania własne w oparciu o wyniki zawarte w przywoływanych raportach z badań CBOS i OBOP. Zestawienie raportów znajduje się w tabelach w aneksie. 
a więc sytuacji, gdy ciąża zagraża życiu lub zdrowiu matki, a także jest skutkiem czynu zakazanego (trzeba pamiętać, że nie chodzi wyłącznie o gwałt), to w przypadku tych przesłanek zdecydowana większość respondentów dopuszczała możliwość aborcji (nie mniej niż 70\%, por. wykresy 3 i 4). Wreszcie jeśli chodzi o ostatnią przesłankę ustawową (legalną do roku 2020) - duże prawdopodobieństwo wad lub chorób płodu, to tutaj wprawdzie aborcję dopuszczał nieco mniejszy odsetek respondentów, ale mimo wszystko było to co najmniej 53\%.

Trzeba $\mathrm{w}$ tym miejscu zauważyć, że w ostatnim z analizowanych badań (CBOS 2020) wątek powyższej przesłanki został rozszerzony, gdyż zadano respondentom trzy bardziej precyzyjne pytania o dopuszczalność przerywania ciąży w sytuacji:

- gdy wiadomo, że dziecko urodzi się upośledzone (odpowiedzi na to pytanie zostały użyte $\mathrm{w}$ porównaniu $\mathrm{z}$ wcześniejszymi badaniami na wykresie 6 - dopuszczane przez $64 \%$ respondentów);

- gdy z badań prenatalnych wynika, że płód ma zespół Downa (dopuszczane przez 38\% respondentów);

- gdy z badań prenatalnych wynika, że płód obarczony jest nieuleczalną chorobą prowadzącą do śmierci (dopuszczane przez 75\% respondentów).

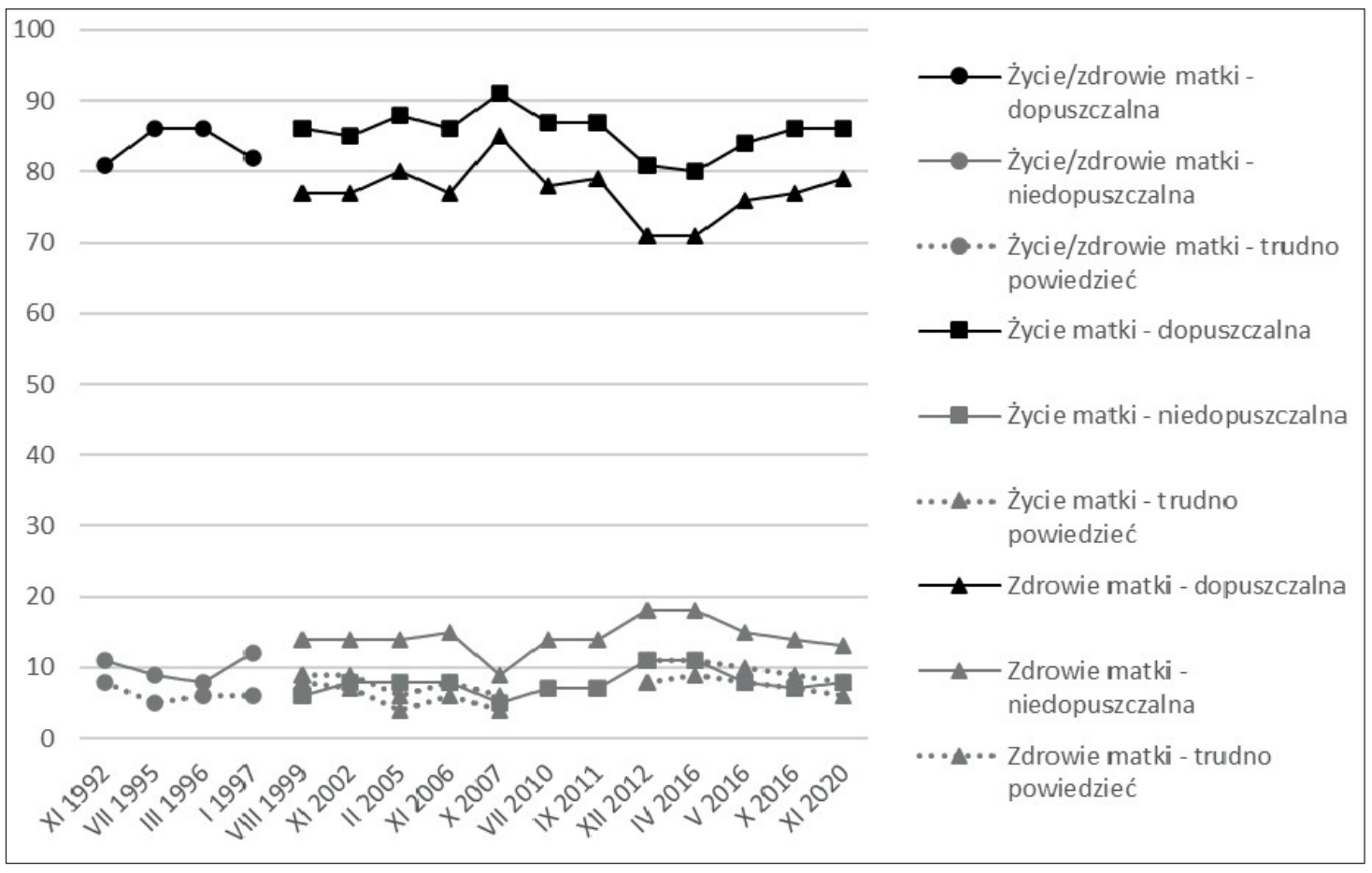

Wykres 3. Dopuszczalność aborcji w sytuacji zagrożenia życia lub zdrowia matki (w procentach) 


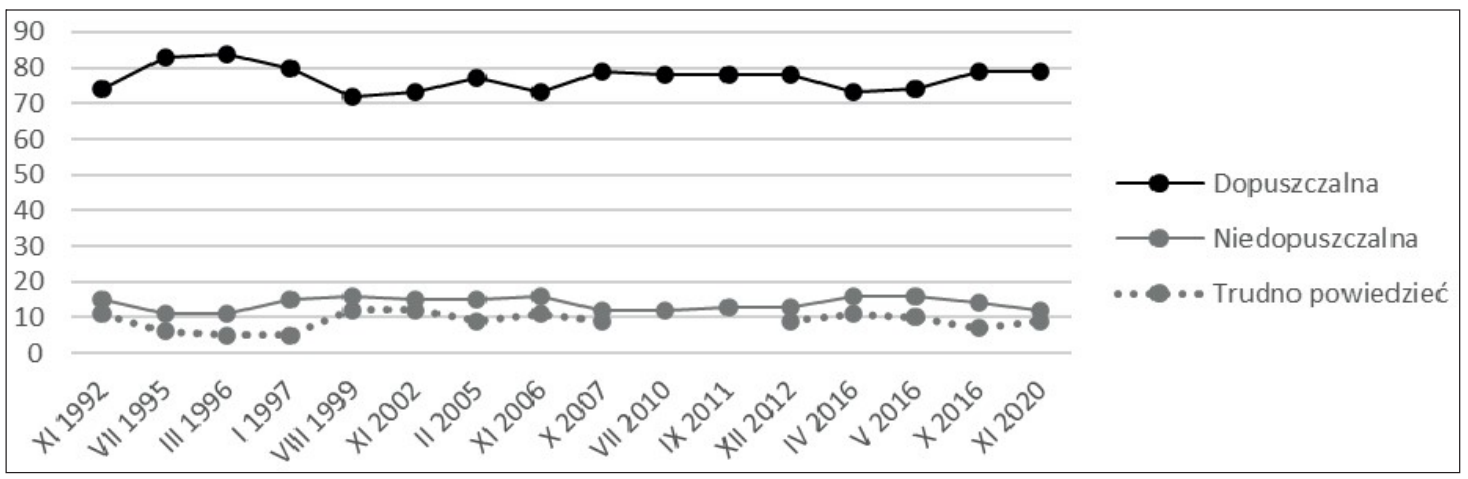

Wykres 4. Dopuszczalność aborcji w sytuacji, kiedy ciąża jest skutkiem czynu zakazanego (w procentach)

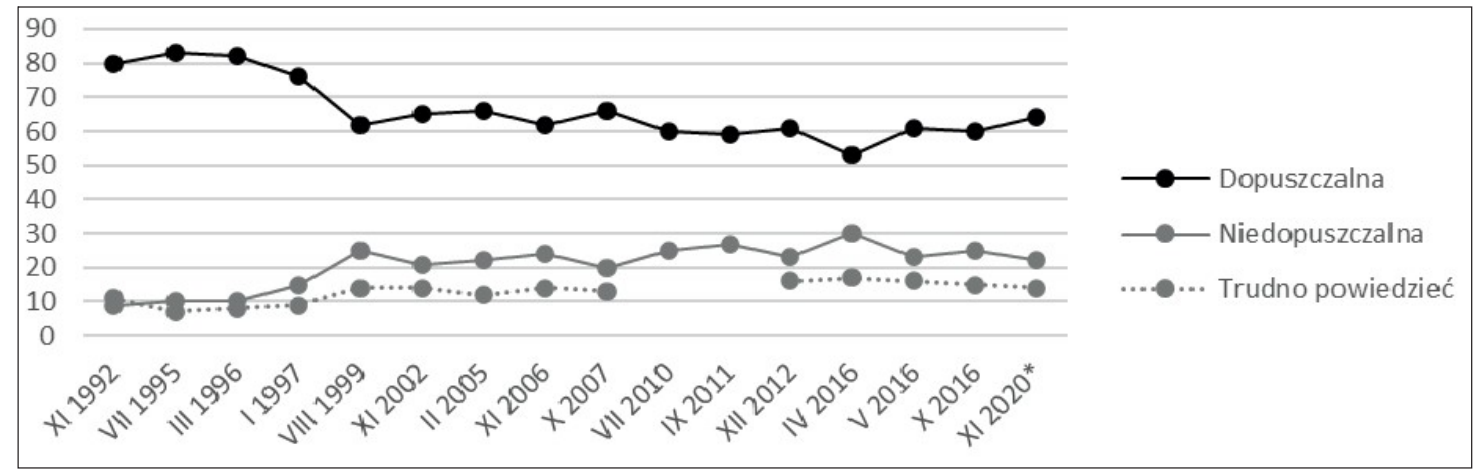

Wykres 5. Dopuszczalność aborcji w przypadku dużego prawdopodobieństwa wad lub chorób płodu (w procentach) ${ }^{6}$

Z kolei przyglądając się odpowiedziom osób przeciętnie i bardziej religijnych (w oparciu o maksymalnie 6 badań z lat 1999-2020, wykresy 6-12), można zauważyć, że jeśli chodzi o aprobatę poszczególnych aspektów aborcji (a więc stanowisko sprzeczne z nauczaniem Kościoła), to w przypadku aborcji z przesłanek ustawowych wyniki uzyskane wśród osób przeciętnie religijnych były bardzo zbliżone do wyników ogółu respondentów (były tylko nieznacznie niższe) - aborcję w analizowanych badaniach dopuszczało odpowiednio:

- ze względu na zagrożenie życia matki - do 91\% respondentów z tej kategorii (w roku 2007), na ogół 4 na 5;

- ze względu na zagrożenie zdrowia matki i pochodzenie ciąży z czynu zakazanego - nie mniej niż 2 na 3 respondentów; pytań.

${ }^{6} \mathrm{Na}$ wykresie gwiazdką oznaczono badanie, w przypadku którego wybrano do porównań 1 z 3 
- wreszcie ze względu na duże prawdopodobieństwo wad/chorób płodu - na ogół połowa i więcej respondentów z tej kategorii (do 64\% w roku 2007, choć w ostatnich 2 badaniach było to poniżej 50\%, w tym w roku 2020 $44 \%)$.

Z kolei w przypadku respondentów bardziej religijnych odsetki były tutaj niższe, ale mimo tego dopuszczało aborcję:

- przynajmniej połowa (najwięcej - 69\% w roku 2007) respondentów w przypadku zagrożenia życia matki;

- od 38\% do $61 \%$ respondentów w przypadku zagrożenia zdrowia matki;

- od $21 \%$ do $44 \%$ respondentów w przypadku, gdy ciąża jest skutkiem czynu zakazanego;

- przynajmniej co piąty w przypadku prawdopodobieństwa wad lub chorób płodu.

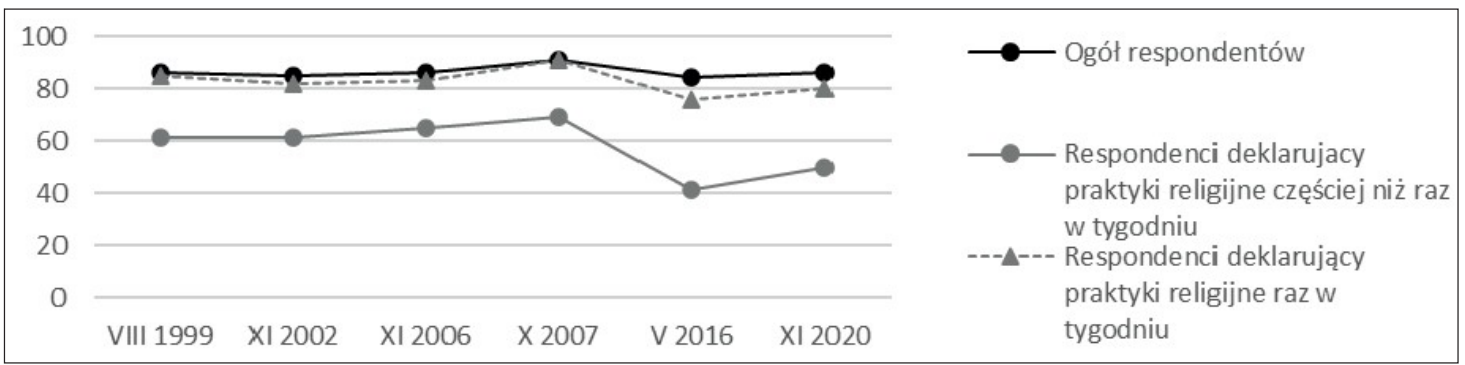

Wykres 6. Dopuszczalność aborcji w sytuacji zagrożenia życia matki - ogół respondentów a respondenci „religijni” (w procentach)

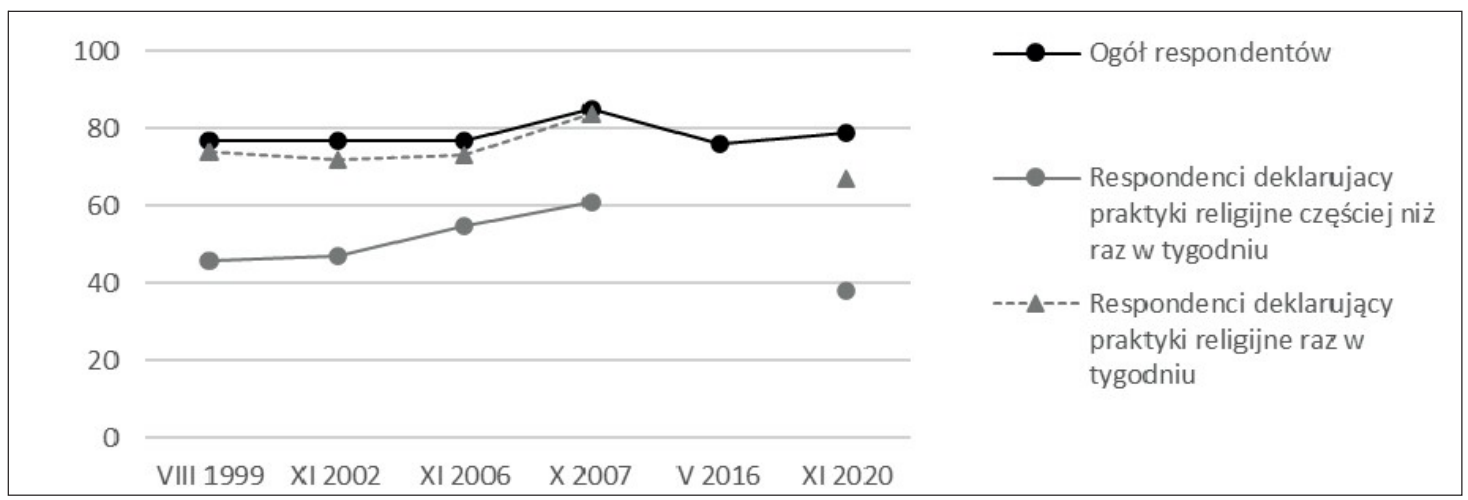

Wykres 7. Dopuszczalność aborcji w sytuacji zagrożenia zdrowia matki - ogół respondentów a respondenci ,religijni” (w procentach) 


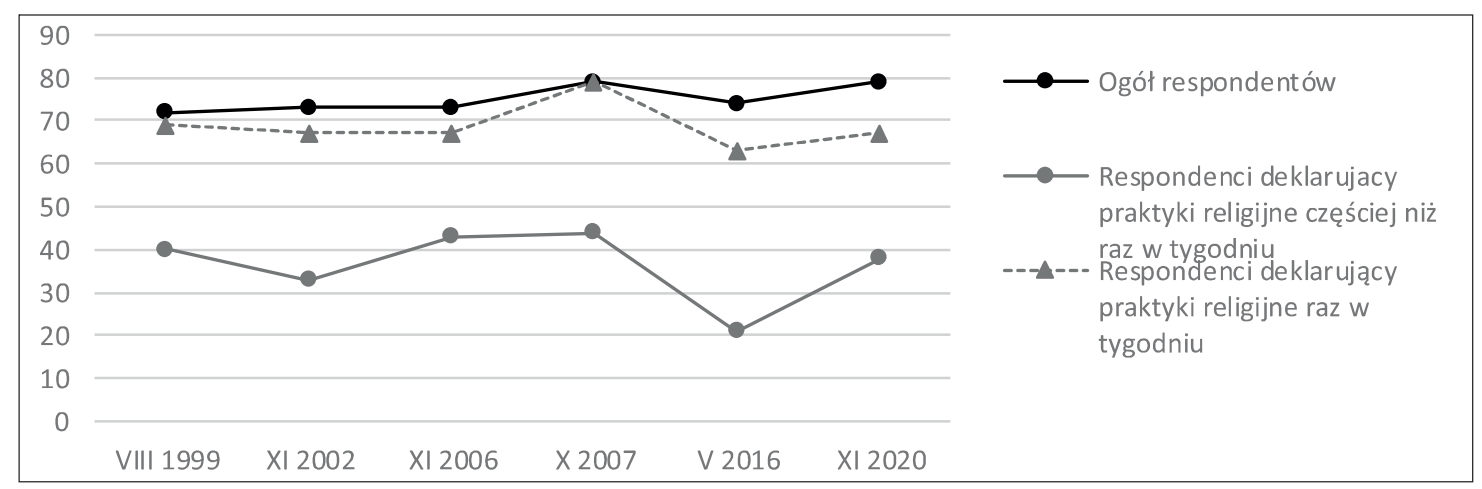

Wykres 8. Dopuszczalność aborcji w sytuacji, kiedy ciąża jest skutkiem czynu zakazanego - ogół respondentów a respondenci „,religijni” (w procentach)

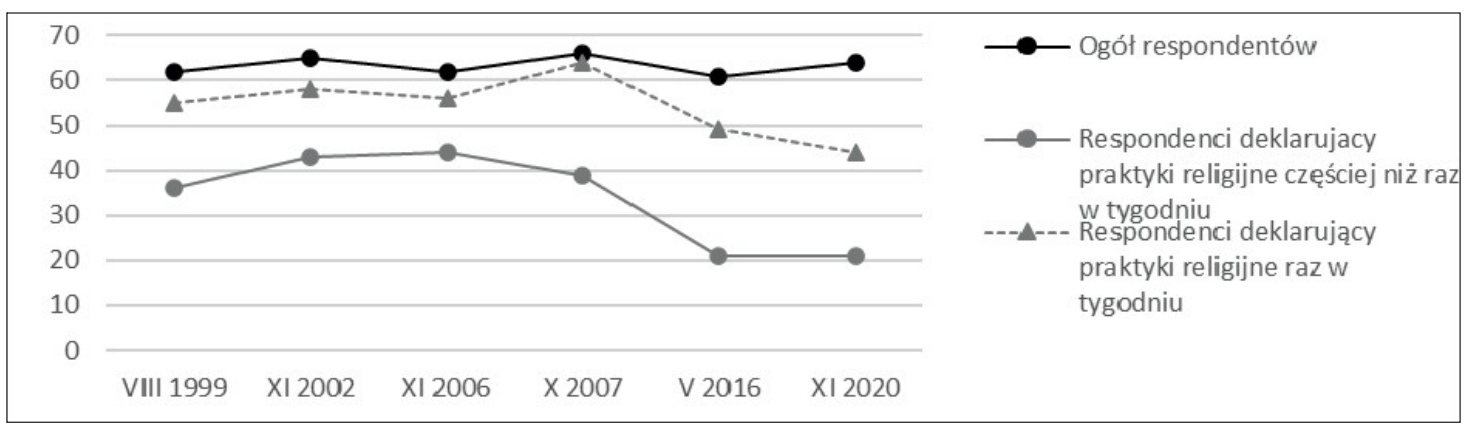

Wykres 9. Dopuszczalność aborcji ze względu na wady lub choroby płodu - ogół respondentów a respondenci ,religijni” (w procentach)

W przypadku przesłanek ,społeczno-ekonomicznych” (wykresy 10 i 11) oraz braku woli, żeby mieć dzieci (wykres 12), akceptacja dla dopuszczalności aborcji była niższa (tak jak wśród ogółu respondentów), choć wśród respondentów przeciętnie religijnych aborcję w przypadku trudnej sytuacji osobistej lub materialnej dopuszczał w niektórych badaniach mniej więcej 1 na 3 respondentów, a w sytuacji, gdy kobieta nie chce mieć dzieci - w niektórych badaniach dopuszczał co piąty respondent (niemniej, w przypadku wszystkich 3 przesłanek w badaniach z roku 2020 odsetki były najniższe z wszystkich dostępnych badań). Z kolei wśród respondentów bardziej religijnych aborcję w przypadku trudnej sytuacji osobistej lub materialnej dopuszczał w niektórych badaniach prawie co 5 respondent, natomiast w sytuacji, gdy kobieta nie chce mieć dzieci - wprawdzie mniej niż co dziesiąty, ale i tak w 2 na 5 badań było to $8 \%$. 


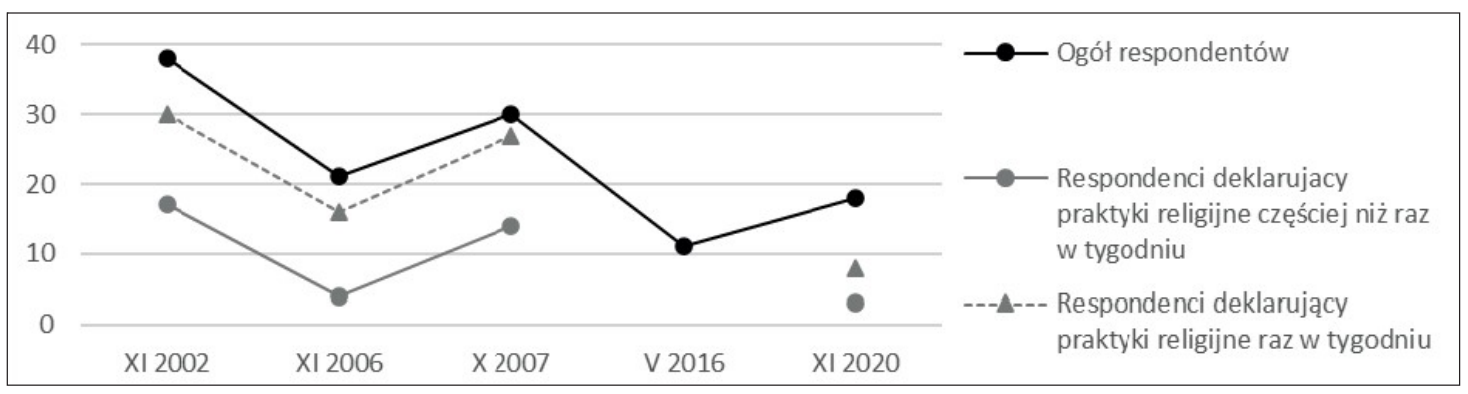

Wykres 10. Dopuszczalność aborcji ze względu na trudną sytuację osobistą kobiety ogół respondentów a respondenci ,religijni” (w procentach)

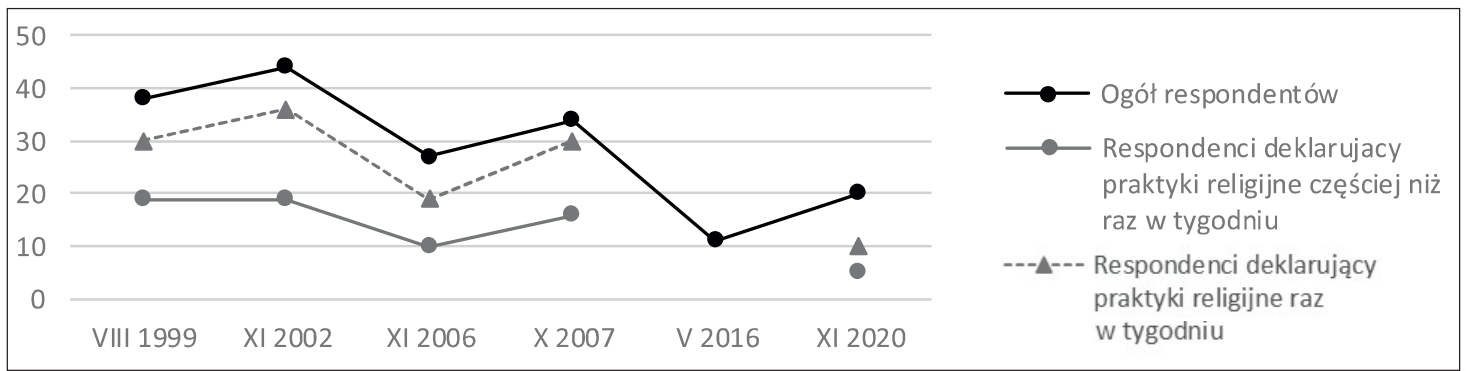

Wykres 11. Dopuszczalność aborcji ze względu na trudną sytuację materialną kobiety - ogół respondentów a respondenci ,religijni” (w procentach)

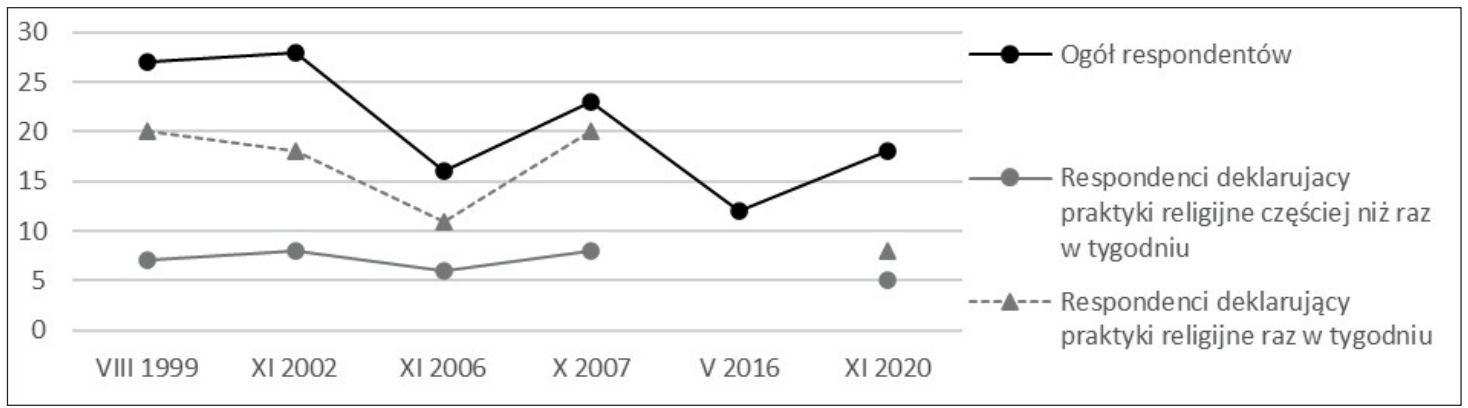

Wykres 12. Dopuszczalność aborcji w sytuacji, gdy kobieta nie chce mieć dzieci ogół respondentów a respondenci ,religijni” (w procentach) 


\subsection{Sztuczne zapłodnienie}

Drugą z kwestii, poruszanych stosunkowo często w badaniach (ostatnio w roku 2015), była dopuszczalność sztucznego zapłodnienia ${ }^{7}$. Była ona analizowana przede wszystkim pod kątem dopuszczalności $\mathrm{w}$ przypadku małżeństw (we wszystkich badaniach), ale od roku 2009 uwzględnione zostały również związki nieformalne oraz kobiety samotne (singielki), co można uzasadnić rozerwaniem związku między małżeństwem i prokreacją w świadomości społecznej. W niektórych badaniach pytano również o gotowość respondentów do skorzystania ze sztucznego zapłodnienia oraz o stosunek do kwestii wytwarzania embrionów nadliczbowych.

Trzeba w tym miejscu wskazać na kontekst, w jakim były stawiane pytania o dopuszczalność sztucznego zapłodnienia $\mathrm{w}$ przypadku niektórych z przywoływanych badań, miał on bowiem znaczenie dla uzyskanych wyników. W przypadku badań z 2003 r. pytanie o in vitro było częścią badań dotyczących bardziej kontrowersyjnego zagadnienia - klonowania (negatywnie ocenianego przez respondentów), można więc przyjąć, że nastawienie do klonowania przełożyło się $\mathrm{w}$ jakimś stopniu w tym badaniu na stosunek do sztucznego zapłodnienia (por. CBOS 2003c) ${ }^{8}$. Badanie z roku 2014 odbiegało również nieco od pozostałych, gdyż respondentów pytano o szereg różnych zachowań, które są uznawane za kontrowersyjne (np. o zabieg in vitro w przypadku małżeństwa, surogację matki na rzecz córki, ale też o nagie opalanie się na jednej plaży kobiet i mężczyzn), przy czym o każdą z badanych kwestii pytano w dwojaki sposób - czy ludzie mają prawo do takiego zachowania oraz czy respondenci uważają to zachowanie za właściwe, przy czym na potrzeby obecnych analiz przyjęto odpowiedzi na pytanie o prawo do danego zachowania. Trzeba zaznaczyć, że respondenci w przypadku sztucznego zapłodnienia nieco częściej przyznawali prawo do skorzystania z zabiegu (85\% za i 9\% przeciw), niż uznawali to za właściwe (79\% - właściwe, 14\% - niewłaściwe) (por. CBOS 2014a).

Jeśli chodzi o dopuszczalność sztucznego zapłodnienia, to spotykało się ono z największą akceptacją w przypadku małżonków, którzy nie mogą mieć dzieci (wykres 13) - akceptowała je zdecydowana większość respondentów (od $52 \%$ do $85 \%$ ), przy czym do wyniku z marca 2003 r. trzeba podchodzić z rezerwą. Ponad połowa respondentów (do 62\%) dopuszczała sztuczne zapłodnienie w przypadku związków nieformalnych (wykres 14). Z kolei w przypadku samotnych kobiet (wykres 15) poziom akceptacji był nieco niż-

\footnotetext{
${ }^{7}$ Kwestia sztucznego zapłodnienia pojawiła się w co najmniej 11 badaniach CBOS z lat 1995-2015. Zestawienie raportów w tabeli $2 \mathrm{w}$ aneksie.

${ }^{8}$ Dość niski poziom akceptacji dla in vitro uzyskano także w badaniach dotyczących klonowania z roku 1997 (por. CBOS 2003c).
} 
szy, jednak zbliżał się do poziomu 50\% (a w przypadku 2 ostatnich badań przeważały odpowiedzi wskazujące na akceptację).

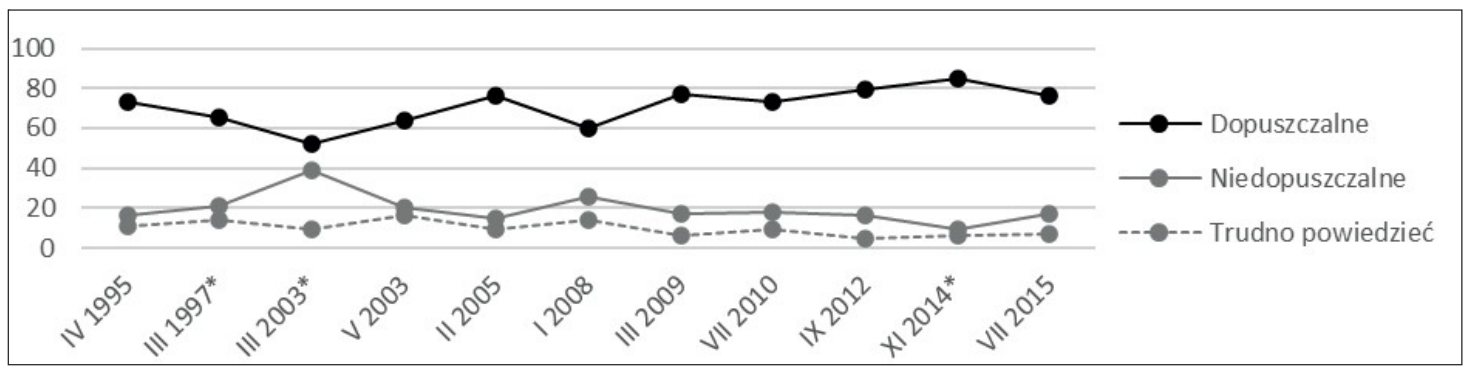

Wykres 13. Dopuszczalność sztucznego zapłodnienia w przypadku małżeństw, które nie mogą mieć dzieci (w procentach) ${ }^{9}$

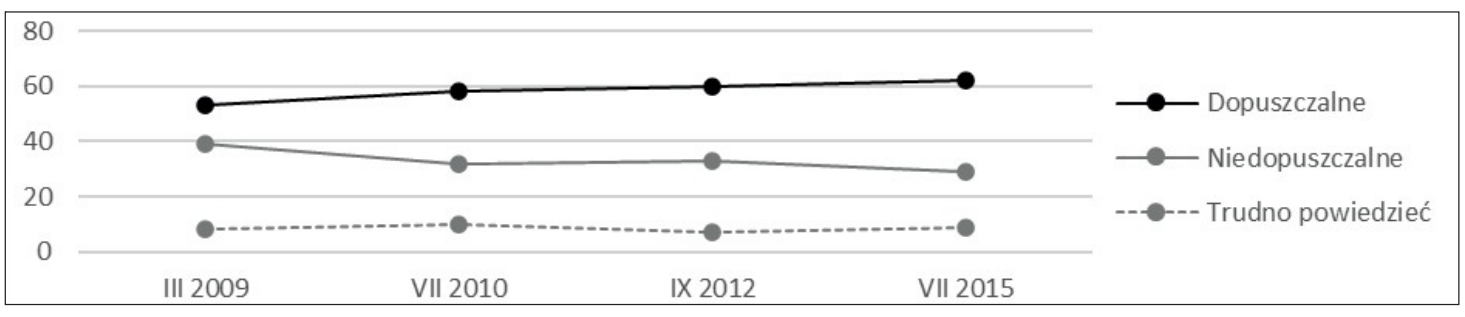

Wykres 14. Dopuszczalność sztucznego zapłodnienia w przypadku związków nieformalnych (w procentach)

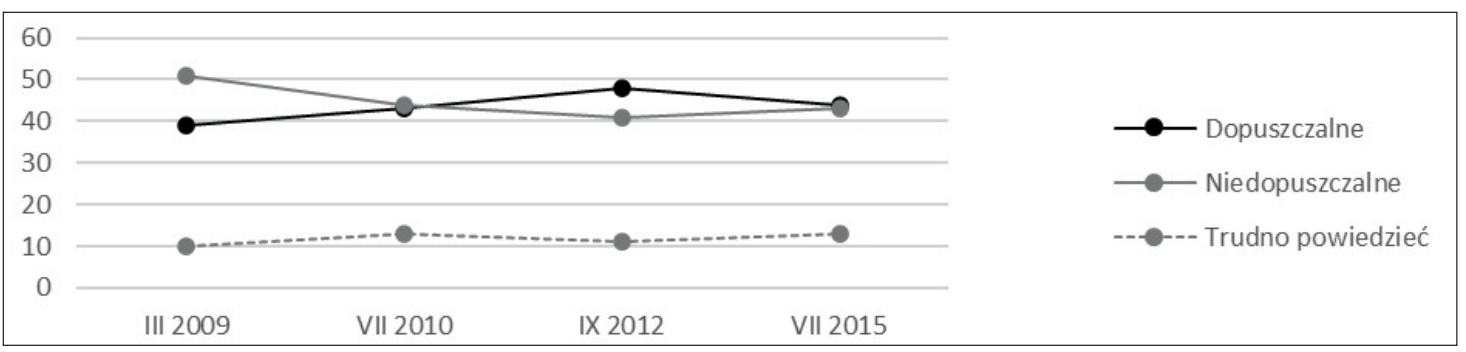

Wykres 15. Dopuszczalność sztucznego zapłodnienia w przypadku samotnych kobiet (w procentach)

${ }^{9} \mathrm{Na}$ wykresie gwiazdką zaznaczono opisane wcześniej badania, które nieco odbiegają od pozostałych badań dotyczących sztucznego zapłodnienia. 
W przypadku pytania o to, czy respondenci sami byliby skłonni skorzystać ze sztucznego zapłodnienia, ponad połowa respondentów (najwięcej w roku $2012-65 \%$ ) udzieliła odpowiedzi pozytywnej, niemniej porównując te wyniki z akceptacją dla dopuszczalności sztucznego zapłodnienia $\mathrm{w}$ przypadku małżeństw, które nie mogą mieć dzieci, było to od $11 \%$ do $14 \%$ mniej odpowiedzi pozytywnych - dopuszczanie w ogóle nie musi oznaczać dopuszczania również w swoim przypadku. Trzeba jednak pamiętać, że znaczenie mógł mieć tutaj wiek - bowiem o ile w przypadku respondentów z grup wiekowych 18-24 i 25-34 lata odsetek odpowiedzi pozytywnych w poszczególnych badaniach oscylował wokół $70 \%$, o tyle np. w przypadku respondentów w wieku 65 i więcej lat (dla których kwestia skorzystania ze sztucznego zapłodnienia wydaje się raczej czysto teoretyczną), odsetek odpowiedzi pozytywnych wahał się w przedziale $27-41 \%$.

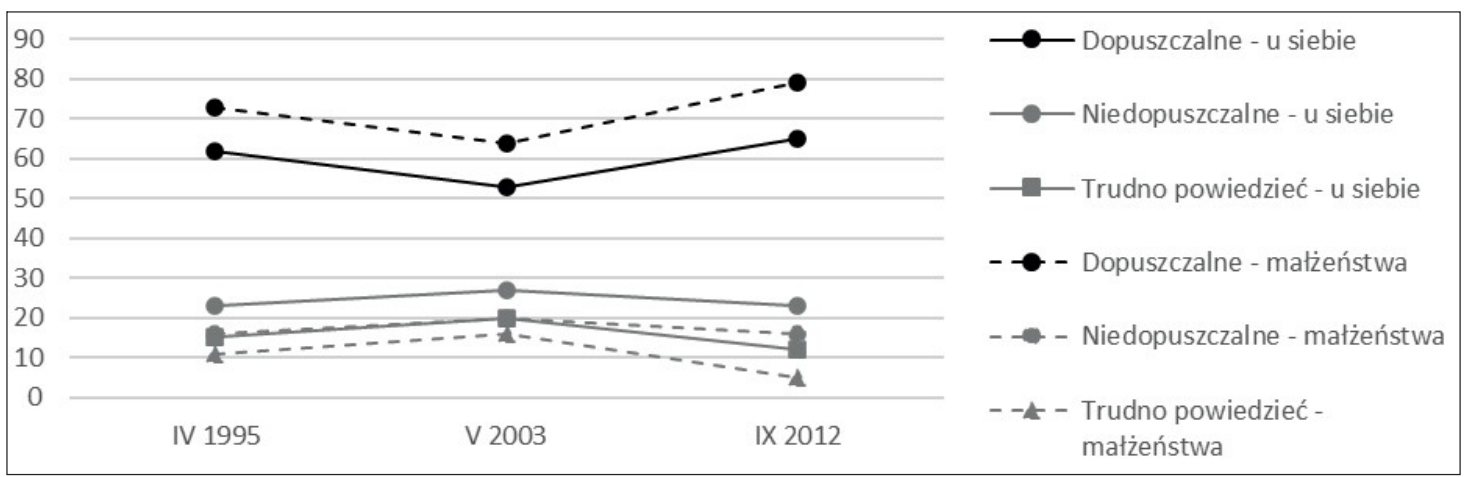

Wykres 16. Dopuszczalność sztucznego zapłodnienia w przypadku małżeństw, które nie mogą mieć dzieci a dopuszczalność sztucznego zapłodnienia u siebie (w procentach)

Wreszcie jeśli chodzi o kwestię embrionów nadliczbowych i ich zamrażania (wykres 17), to ponad połowa respondentów skłonna była dopuszczać takie rozwiązanie (w zależności od badania 52-60\%).

Przyglądając się zestawieniu odpowiedzi ogółu respondentów z odpowiedziami respondentów przeciętnie i bardziej religijnych (wykresy 18-20), widać, że odpowiedzi osób przeciętnie religijnych były w zasadzie zbliżone do odpowiedzi ogółu respondentów, na nieco tylko niższym poziomie. W przypadku małżeństw, które nie mogą mieć dzieci, sztuczne zapłodnienie dopuszczało w zależności od badania od 55\% do 77\% respondentów z tej kategorii, w przypadku związków nieformalnych - do 50\%, a w przypadku kobiet samotnych - do 39\%. Jeśli chodzi o osoby bardziej religijne, to w tej kategorii odsetki były niższe, ale 
i tak sztuczne zapłodnienie w przypadku małżeństw dopuszczało w zależności od badania od $38 \%$ do $61 \%$ respondentów, w przypadku związków nieformalnych - do 35\% badanych, a w przypadku kobiet samotnych - do 25\% badanych.

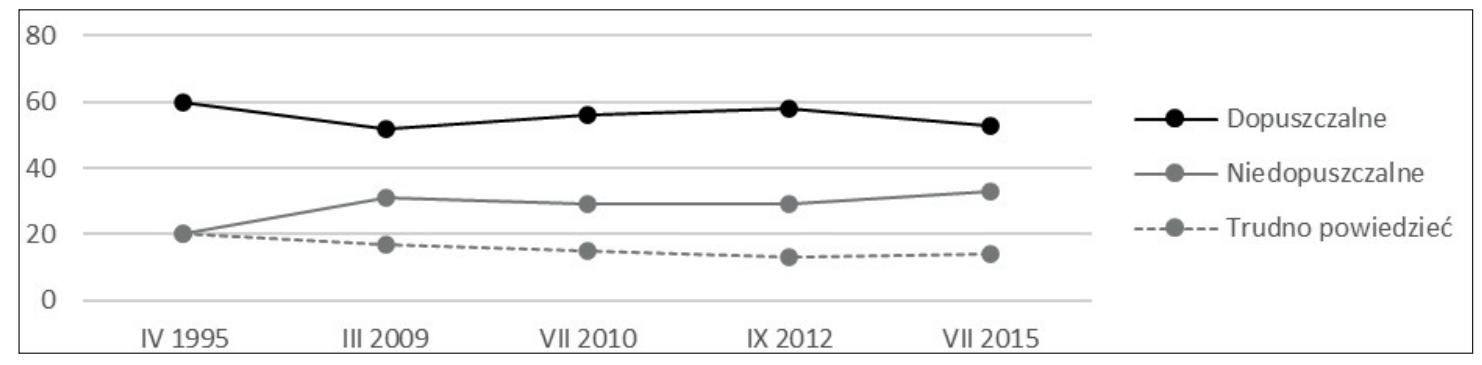

Wykres 17. Dopuszczalność wytwarzania nadliczbowych zarodków (w procentach)

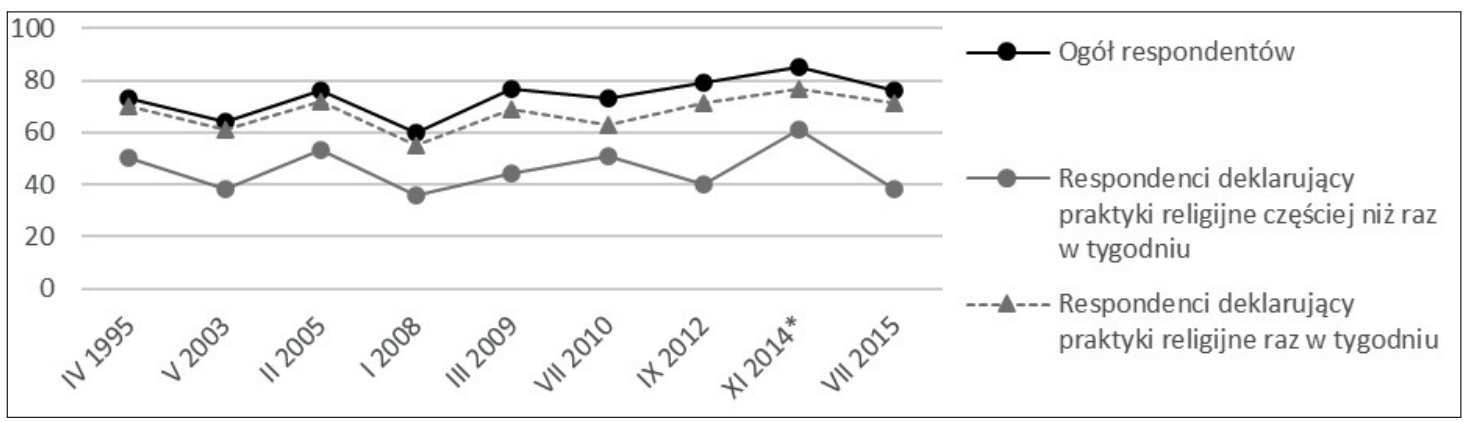

Wykres 18. Dopuszczalność sztucznego zapłodnienia w przypadku małżeństw, które nie mogą mieć dzieci - ogół respondentów a respondenci „religijni” (w procentach) ${ }^{10}$

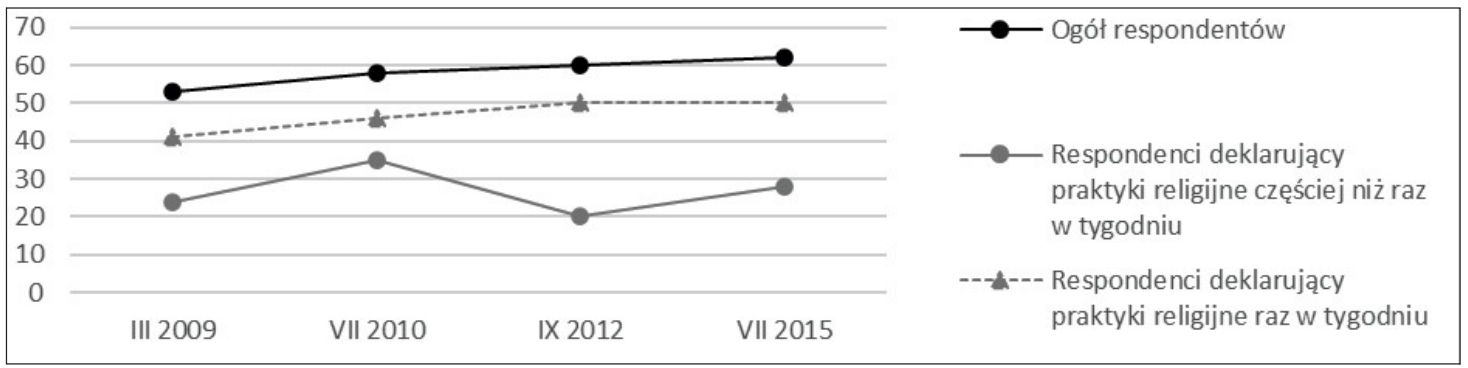

Wykres 19. Dopuszczalność sztucznego zapłodnienia w przypadku związków nieformalnych - ogół respondentów a respondenci „religijni” (w procentach)

\footnotetext{
${ }^{10}$ Por. uwaga z przypisu 9.
} 


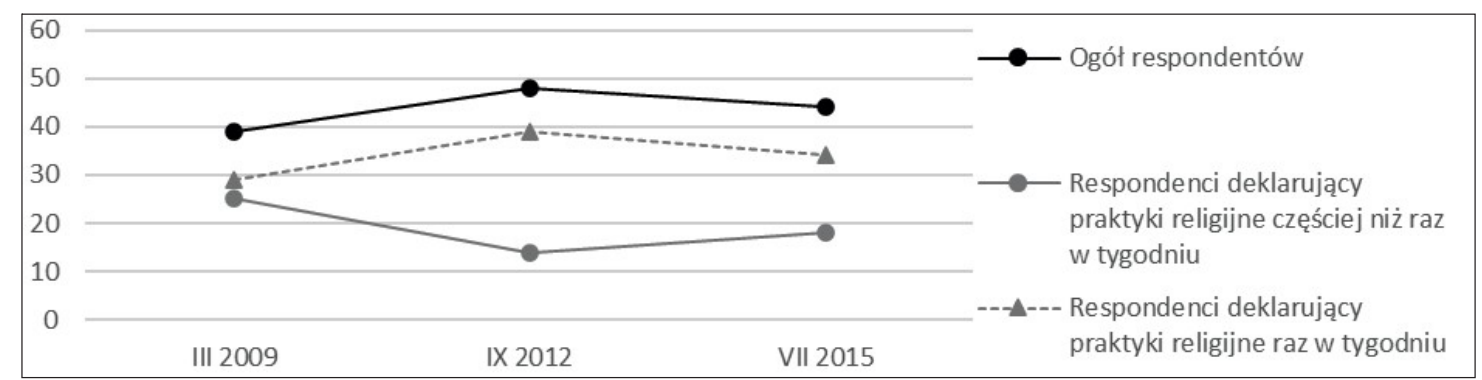

Wykres 20. Dopuszczalność sztucznego zapłodnienia w przypadku samotnych kobiet - ogół respondentów a respondenci „religijni” (w procentach)

Relatywnie wielu respondentów ze wspomnianych dwóch kategorii było skłonnych zaakceptować sztuczne zapłodnienie w swoim przypadku - u osób przeciętnie religijnych była to co najmniej połowa respondentów, a u bardziej religijnych - przynajmniej co czwarty.

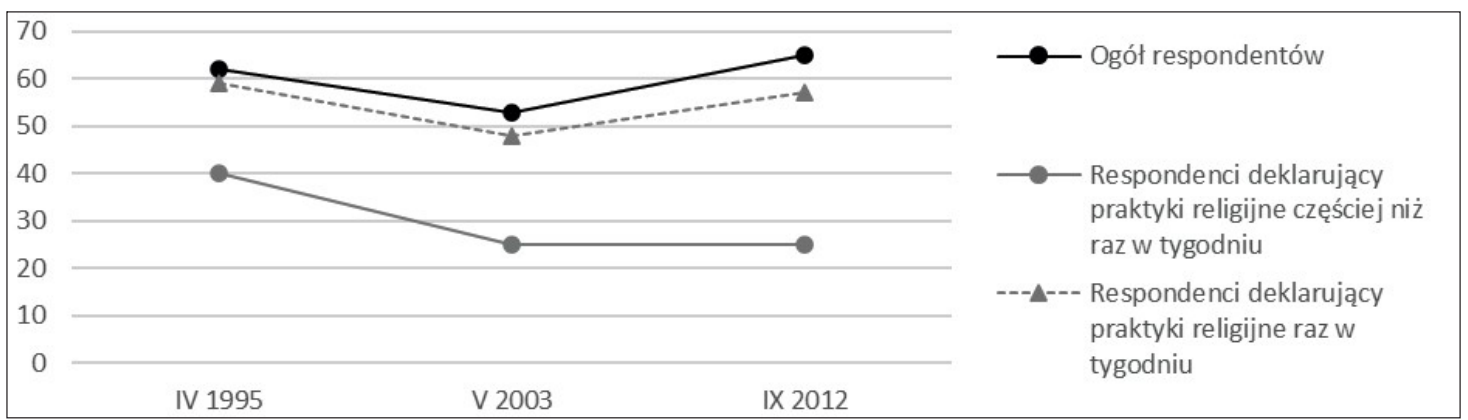

Wykres 21. Dopuszczalność sztucznego zapłodnienia u siebie - ogół respondentów a respondenci ,religijni” (w procentach)

Również jeśli chodzi o kwestię embrionów nadliczbowych, to dopuszczało je nie mniej niż $42 \%$ respondentów przeciętnie religijnych ( $w$ jednym z badań ponad połowa), natomiast w przypadku bardziej religijnych wprawdzie tendencję można uznać za spadkową i w ostatnim $\mathrm{z}$ analizowanych badań było to $17 \%$ (a więc prawie co piąty respondent), niemniej w roku 1995 było to $39 \%$ (wykres 22).

W kontekście rozważań nad sztucznym zapłodnieniem warto zwrócić uwagę na znamienne wyniki, jakie uzyskano w roku 2010 (CBOS 2010b). Pytano wówczas respondentów o to, jaki jest stosunek Kościoła katolickiego do stosowania zapłodnienia in vitro. $85 \%$ respondentów prawidłowo wskazało, że Kościół je 
potępia. Jednak kiedy respondenci oceniali, czy popełniają grzech: 1) lekarze wykonujący zabieg in vitro, 2) kobiety temu zabiegowi się poddające, 3) politycy stanowiący prawo dotyczące sztucznego zapłodnienia, 4) osoby popierające takie prawo - to ponad $2 / 3 \mathrm{z}$ nich uznało, że wymienione osoby nie popełniają grzechu.Warto zauważyć, że wśród respondentów bardziej religijnych odsetki odpowiedzi o popełnianiu bądź nie popełnianiu grzechu przez kobiety i polityków były praktycznie równe (43\% uznało, że kobieta poddająca się zabiegowi popełnia grzech, $41 \%$ - że grzechu nie popełnia; w przypadku polityków stanowiących prawo związane z in vitro było to odpowiednio $41 \%$ i $40 \%$ ).

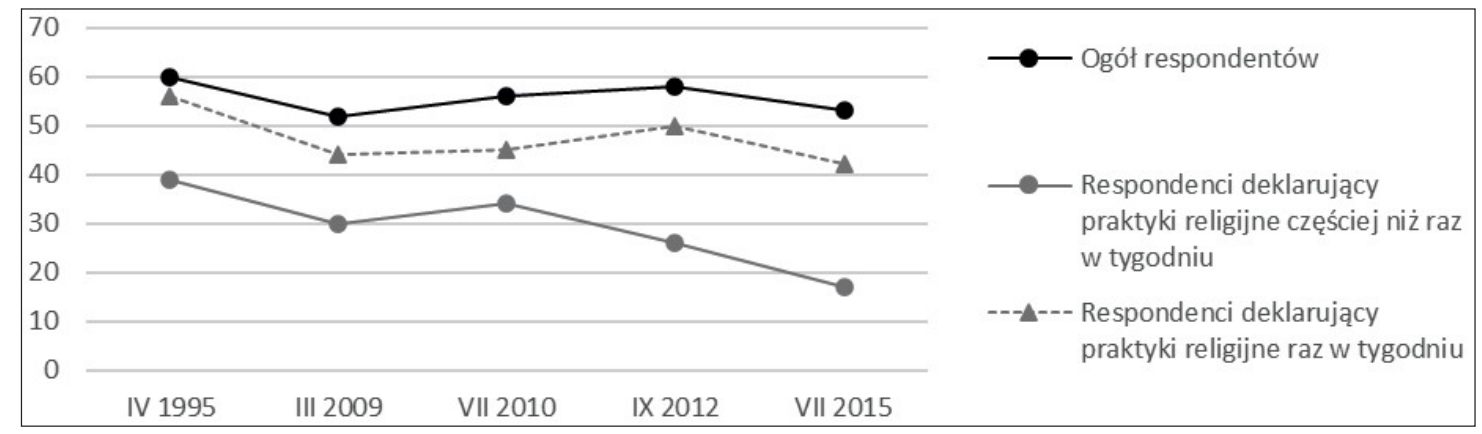

Wykres 22. Dopuszczalność wytwarzania nadliczbowych zarodków - ogół respondentów a respondenci „religijni” (w procentach)

\subsection{Antykoncepcja}

Kolejna kwestia, mniej rozbudowana jeśli chodzi o aspekty brane pod uwagę $\mathrm{w}$ badaniach, to antykoncepcja ${ }^{11}$, w przypadku której trzeba jednak zwrócić uwagę na dość zróżnicowany sposób formułowania pytań (pojawiają się pytania o potępienie stosowania antykoncepcji, są pytania o ocenę, czy to coś dobrego czy złego, czy jest dopuszczalna, czy nie, a w niektórych badaniach odpowiedzi udzielane były na skali liczbowej, co pozwala na udzielenie odpowiedzi ambiwalentnej).

Niezależnie jednak od sposobu sformułowania pytania i proponowanej formy odpowiedzi zdecydowanie ponad połowa respondentów (tylko raz było to $48 \%$, a więc prawie połowa) dopuszczała stosowanie antykoncepcji, przy czym w ostatnim z dostępnych badań było to $77 \%$. Jeśli w analizie nie weźmie się pod uwagę badań z pytaniami opartymi na skali, która daje na ogół

${ }^{11}$ Wątek antykoncepcji i jej dopuszczalności pojawił się w 10 badaniach, po raz pierwszy już w roku 1980, ostatnio w roku 2014. Zestawienie raportów w tabeli 3 w aneksie. 
możliwość wskazania na środku odpowiedzi ambiwalentnych (na wykresie 23 oznaczone dwiema gwiazdkami), wówczas aprobata nie spadała poniżej $60 \%$.

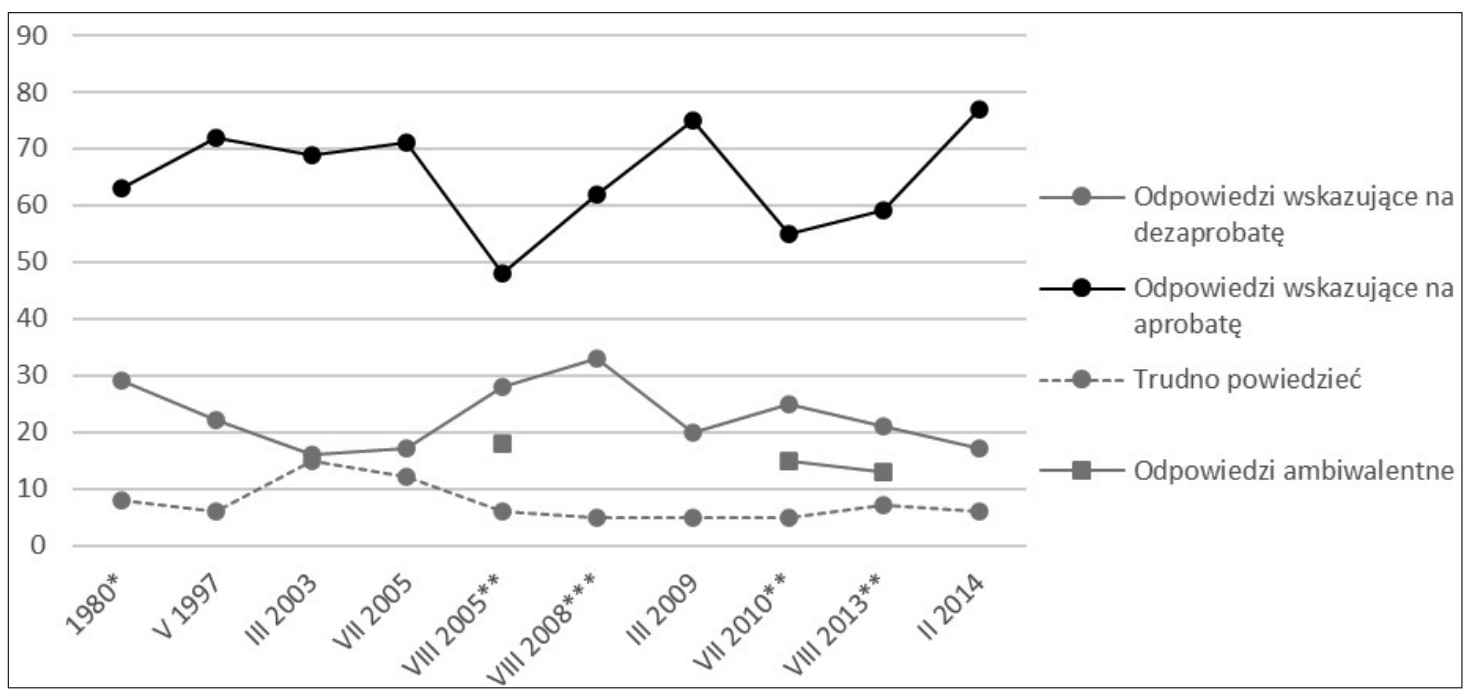

Wykres 23. Dopuszczalność antykoncepcji - z uwzględnieniem badań z pytaniami opartymi na skali liczbowej (w procentach) ${ }^{12}$

W przypadku antykoncepcji mniejsza była możliwość porównania odpowiedzi ogółu respondentów i osób religijnych ze względu na małą liczbę raportów zawierających pełne dane - zaledwie 2 badania CBOS i 1 badanie TNS OBOP, przy czym różniły się one sposobem określenia poziomu zaangażowania religijnego. W przypadku badań CBOS z lat 2009 i 2014 antykoncepcję akceptowało odpowiednio $66 \%$ i $76 \%$ osób deklarujących praktyki religijne raz w tygodniu oraz odpowiednio $46 \%$ i $41 \%$ osób deklarujących praktyki częściej niż raz w tygodniu. W badaniu TNS OBOP z roku 2005 jako dobrą oceniało antykoncepcję $66 \%$ respondentów, którzy określali się jako wierzący regularnie praktykujący (por. CBOS 2009b; CBOS 2014b; TNS OBOP 2005).

$12 \mathrm{~W}$ badaniach z lat 2005, 2010 i 2013 (oznaczone **) respondenci zaznaczali odpowiedzi na skali od 1 do 7, co spowodowało, że odpowiedzi ze środka skali (4) należy uznać za ambiwalentne (jako dodatkowa odpowiedź oprócz „trudno powiedzieć”).W badaniu z roku 2008 (oznaczone ***) respondenci zaznaczali odpowiedzi na skali od 1 do 10, w związku z czym nie miała ona pozycji ambiwalentnej. Wyniki badania z roku 1980 (oznaczone *) zostały zamieszczone w raporcie z roku 1997. 


\subsection{Eutanazja}

Ostatnie z zagadnień to eutanazja ${ }^{13}$, w przypadku której warto odnotować, że $w$ badaniach poruszających ten problem podejmowane były również inne kwestie bioetyczne, które wprawdzie nie są eutanazją, ale bywają z nią kojarzone (chodzi np. o kwestie zaprzestania uporczywej terapii itd.). Dlatego należy doprecyzować, że kiedy jest tu mowa o eutanazji, to przywoływane wyniki dotyczą sytuacji, kiedy lekarz doprowadza do zakończenia życia pacjenta na jego wyraźną prośbę, wyrażoną świadomie - a więc eutanazję czynną dobrowolną (por. np. Zawadka i Balicki 2015); innych możliwości, które mogą mieścić się $w$ ramach pojęcia eutanazja, nie brano pod uwagę. Trzeba też zauważyć, że w trzech badaniach (z lat 1999, 2005, 2013) w zasadzie zadawano po dwa pytania dotyczące tego samego zagadnienia, ale sformułowane w różny sposób - np. w roku 2005 raz zadano pytanie o zakończenie życia osoby dorosłej, ale nie używano nazwy eutanazja, problem przedstawiono opisowo, a raz zadano pytanie po prostu o eutanazję. W przypadku pierwszego pytania, w którym eutanazja nie została wymieniona z nazwy, odpowiedzi wskazujących na aprobatę udzieliło 51\% respondentów, gdy pojawiła się nazwa - już tylko 35\%.

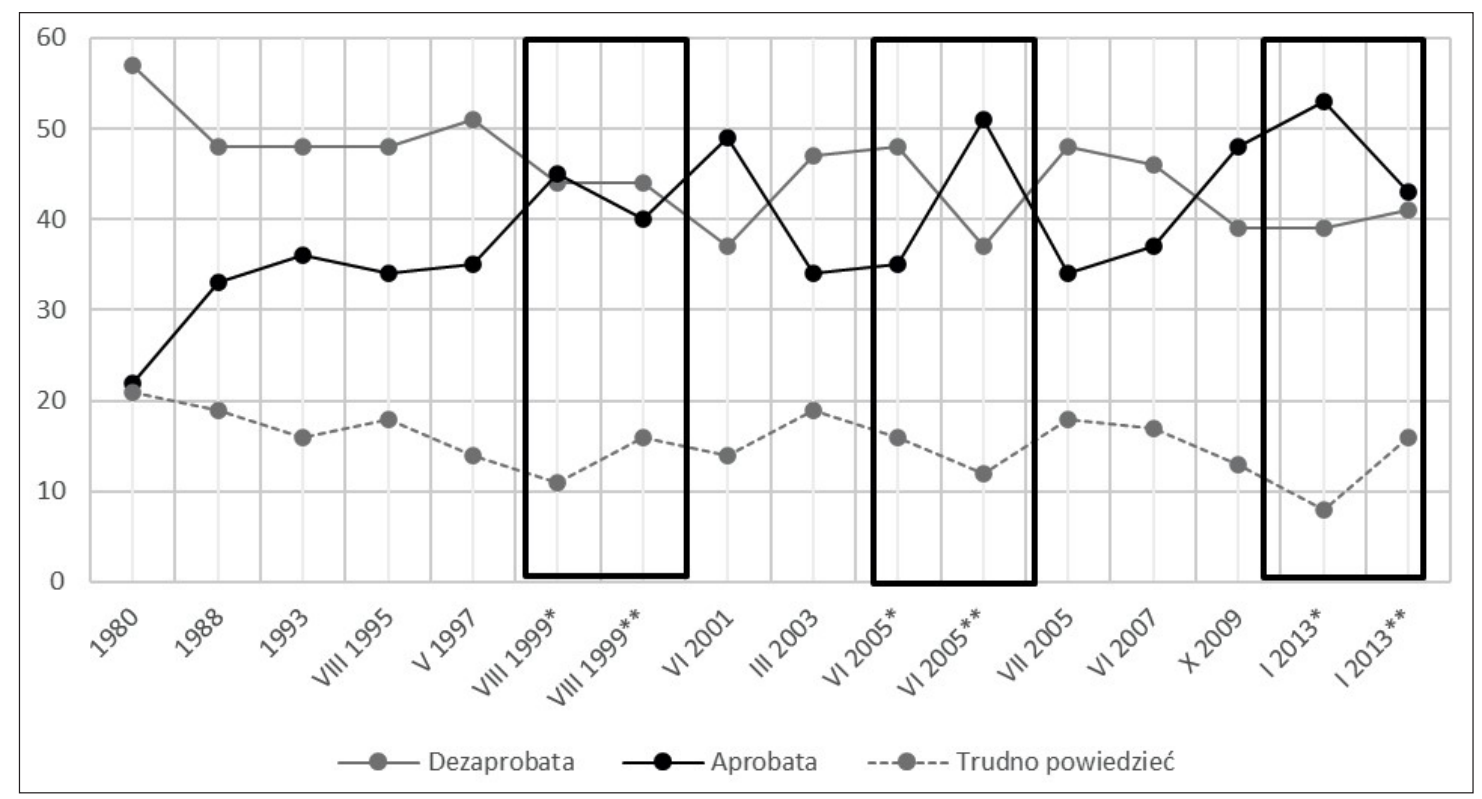

Wykres 24. Dopuszczalność eutanazji (w procentach) $)^{14}$

${ }^{13}$ Wątek eutanazji pojawił się w co najmniej 16 badaniach CBOS i OBOP (i jego następców) w latach 1980-2013. Zestawienie raportów w tabeli $4 \mathrm{w}$ aneksie.

${ }^{14}$ Badanie z roku 1999: wyniki dla pytania: „Przedstawię teraz Panu(i) kilka sytuacji dotyczących osób chorych bliskich śmierci, nieuleczalnych, cierpiących. Czy uznał(a)by Pan(i) za dopuszczalne czy też za niedopuszczalne spowodowanie bezbolesnego zakończenia życia, jeśli pacjent 
W analizowanych badaniach na dopuszczalność eutanazji wskazywało od $22 \%$ do $53 \%$ respondentów, przy czym w niektórych badaniach przeważa aprobata dla eutanazji, w innych - dezaprobata. W 7 badaniach (wykres 25), w których oprócz tradycyjnej formy odpowiedzi poproszono respondentów również o zaznaczenie odpowiedzi na skali (która dawała możliwość udzielania odpowiedzi ambiwalentnych), to w przypadku tych pytań zawsze było więcej przeciwników niż zwolenników eutanazji.

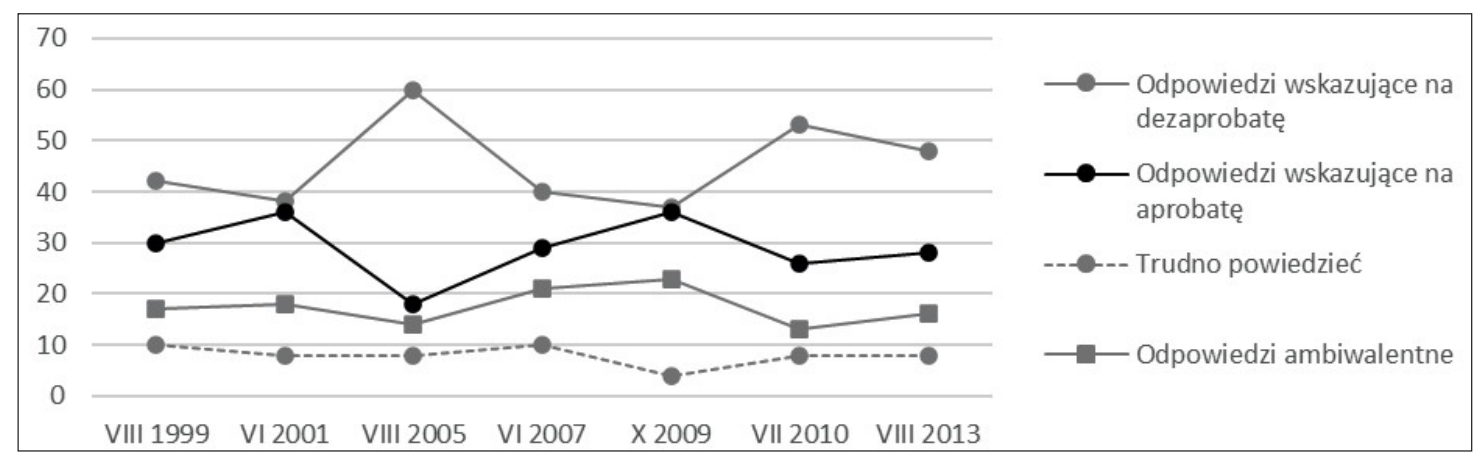

Wykres 25. Dopuszczalność eutanazji - pytania oparte na skali (w procentach) $)^{15}$

Porównanie odpowiedzi ogółu respondentów oraz osób przeciętnie i bardziej religijnych pokazuje, że również w przypadku eutanazji poziom akceptacji przez respondentów $\mathrm{z}$ tych dwóch kategorii był niższy w porównaniu $\mathrm{z}$ ogółem respondentów, przy czym w przypadku osób bardziej religijnych można odnotować delikatną tendencję wzrostową, gdzie eutanazję dopuszczał w niektórych badaniach prawie co trzeci respondent.

w takiej sytuacji w pełni świadomie o to prosi, a nie może tego uczynić sam?" oznaczono (*), wyniki dla pytania: „Czy, Pana(i) zdaniem, lekarze powinni spełniać wolę cierpiących, nieuleczalnie chorych, którzy domagają się podania im środków powodujących śmierć?” oznaczono (**) (CBOS 1999b). Badanie z roku 2005: wyniki dla pytania: „Czy, ogólnie rzecz biorąc, popiera czy też nie popiera Pan(i) zjawiska, jakim jest eutanazja?” oznaczono (*), wyniki dla pytania: „Czy, Pana(i) zdaniem, w przypadku osób dorosłych dopuszczalne czy też niedopuszczalne jest podanie silnej dawki leków przyspieszających śmierć chorego w ostatnim stadium nieuleczalnej choroby, jeśli bardzo cierpi i świadomie o to prosi?" oznaczono (**) (CBOS 2005b). Badanie z roku 2013: wyniki dla pytania: „Czy uznał(a)by Pan(i) za dopuszczalne czy też za niedopuszczalne podanie przez lekarza środków przyspieszających śmierć ciężko i nieuleczalnie choremu, cierpiącemu pacjentowi, jeśli jest w pełni świadomy i sam o to prosi?” oznaczono (*), wyniki dla pytania: „Czy, Pana(i) zdaniem, lekarze powinni spełniać wolę cierpiących, nieuleczalnie chorych, którzy domagają się podania im środków powodujących śmierć?" oznaczono (**) (CBOS 2013b).

${ }^{15} \mathrm{~W}$ badaniach z lat 2005, 2010 i 2013 skala miała 7 punktów (4 oznaczała odpowiedź ambiwalentną), w latach 1999, 2001, 2007 i 2009 - skala miała 10 punktów, za odpowiedź ambiwalentną uznano w raportach wskazania na 5 i 6 (są ujęte w raportach łącznie). 


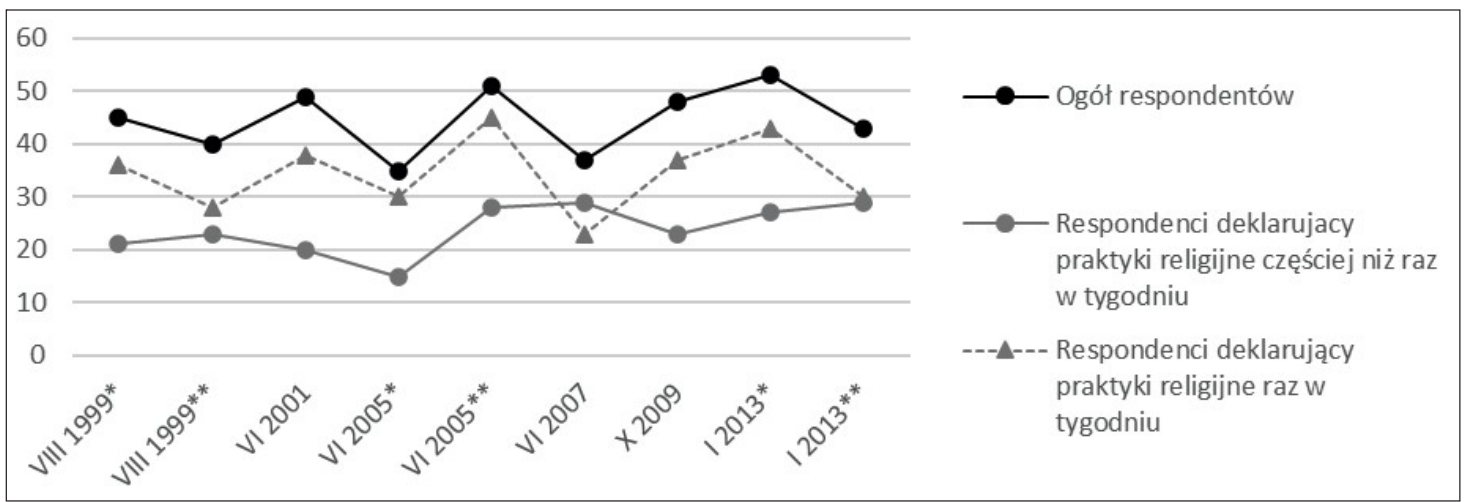

Wykres 26. Dopuszczalność eutanazji - ogół respondentów a respondenci „religijni” (w procentach) $)^{16}$

\section{Wyniki badań - wnioski, pytania}

Przywołane wyżej wyniki badań dotyczących stosunku Polaków, a w tym szczególnie osób deklarujących przynajmniej przeciętny poziom praktyk religijnych, skłaniają do kilku wniosków i pytań (niekoniecznie nowych), które należy potraktować jako punkt wyjścia do dalszych dyskusji, badań i analiz.

Pierwszy z nich dotyczy opinii o dopuszczalności aborcji. O ile w przypadku przyczyn, które nie są dozwolone przez polskie prawo (trudna sytuacja materialna lub osobista kobiety; sytuacja, kiedy kobieta po prostu nie chce mieć dzieci), zdecydowana większość respondentów była w analizowanych badaniach przeciwna dopuszczalności aborcji, o tyle w przypadku przesłanek, które zostały dopuszczone w Ustawie (1993) (niezależnie od tego, czy nadal wszystkie obowiązują), były one przez zdecydowaną większość respondentów akceptowane. Jakkolwiek jeśli nie były one przez nich traktowane jako zwykłe narzędzie kształtowania liczby potomstwa, to jednak wydają się dla nich swego rodzaju „wyjściami bezpieczeństwa” w sytuacjach kryzysowych - np. w sytuacji, kiedy kobieta, której życie bądź zdrowie jest zagrożone w związku z ciążą, jest już matką innych dzieci i pojawia się problem, który dotyczy nie tylko życia matki, ale także wyboru między dobrem dziecka nienarodzonego i jego starszego rodzeństwa. Być może lata obowiązywania przepisów dopuszczających aborcję we wspomnianych sytuacjach odcisnęły swoiste piętno na świadomości społecznej. Trzeba jednak zauważyć, że badania z ostatnich 5 lat (pokrywające się czasowo $\mathrm{z}$ różnymi inicjatywami $\mathrm{w}$ zakresie zmiany prawa dotyczącego aborcji oraz protestami społecznymi przeciw zaostrzeniu przepisów) mogą sygnalizować nadchodzącą liberalizację nastawienia respon-

\footnotetext{
${ }^{16}$ Uwaga dotycząca pytań w badaniach z roku 1999, 2005 i 2013 - por. przypis 14.
} 
dentów do kwestii dopuszczalności aborcji: zauważalne są wzrosty odsetków odpowiedzi wskazujących na dopuszczalność aborcji i spadki odsetków odpowiedzi sprzeciwiających się jej, nawet jeśli nie zmienia to na razie ogólnego rozkładu odpowiedzi w przypadku poszczególnych przesłanek. Jeśli chodzi o przesłanki niedopuszczane przez prawo, może to - jak się wydaje - oznaczać początek zmiany pewnego trendu, który był zauważalny od lat 90 . ubiegłego wieku (wzrost dezaprobaty i spadek aprobaty), choć na razie jest jeszcze za mało wyników badań, żeby można było to jednoznacznie stwierdzić. Biorąc jednak pod uwagę sytuację społeczną i polityczną - jak chociażby uchwaloną przez Parlament Europejski w czerwcu 2021 r. rezolucję, według której dostęp do bezpiecznej i legalnej aborcji jest prawem człowieka (por. Rp.pl 2021), nawet jeśli nie jest ona traktowana jako metoda antykoncepcji (por. Deneka 2021) - która niewątpliwie znajdzie swe odbicie również w świadomości społecznej, można w kolejnych badaniach spodziewać się wzrostu aprobaty dla dopuszczalności aborcji również w tych przypadkach, których prawo obecnie nie dopuszcza.

W tym miejscu nasuwa się pytanie, czy delegalizacja jednej z przesłanek dopuszczalności aborcji (uznanie jej przez Trybunał Konstytucyjny za niezgodną z konstytucją), będącej zresztą w ostatnich latach podstawą niemal wszystkich legalnych aborcji w Polsce (por. Gębka 2018), paradoksalnie w dłuższej perspektywie czasowej nie doprowadzi jednak do liberalizacji przepisów dotyczących aborcji, co może mieć również wpływ na pozostałe analizowane tutaj kwestie. W tym kontekście prawdziwa może okazać się obiegowa opinia, że czasem „lepiej” znaczy jednak „gorzej” (patrząc z punktu widzenia środowisk pro-life).

Z perspektywy Kościoła i jego nauczania za niepokojące można uznać z kolei odpowiedzi respondentów bardziej religijnych, bowiem znaczny ich odsetek w przypadku przesłanek określonych wcześniej jako „wyjścia bezpieczeństwa” był skłonny aborcję dopuścić (w części badań w przypadku zagrożenia zdrowia lub życia matki była to większość), nie wspominając o przeciętnie religijnych, których odpowiedzi tylko nieznacznie odbiegały od odpowiedzi ogółu respondentów. Pojawia się zatem pytanie o motywacje takich odpowiedzi.

W przypadku aborcji warte odnotowania są również wyniki badań z roku 2020, w których zróżnicowano pytanie o dopuszczalność aborcji ze względu na wady lub choroby płodu, wprowadzając różne warianty (upośledzenie, zespół Downa, nieuleczalna choroba prowadząca do śmierci). O ile bowiem w sytuacji, kiedy mowa jest o bliżej niedoprecyzowanych upośledzeniach i śmiertelnych chorobach, które mogą być dla respondentów abstrakcyjne (a także względnie rzadko występować) - aborcję dopuszczało od $64 \%$ do $75 \%$ badanych, natomiast w przypadku zespołu Downa aborcję dopuszcza- 
ło jedynie $38 \%$ badanych (podczas gdy $46 \%$ było jej przeciwnych). Kwestia osób z zespołem Downa, tego jak funkcjonują i radzą sobie w życiu, była $\mathrm{w}$ ostatnich latach wielokrotnie podnoszona $\mathrm{w}$ przestrzeni publicznej i funkcjonuje w świadomości społecznej, część respondentów może mieć również doświadczenie kontaktu z takimi osobami, a to - jak się zdaje - może mieć przełożenie na niższą akceptację dla aborcji w tym przypadku ${ }^{17}$.

Drugie $\mathrm{z}$ analizowanych zagadnień - sztuczne zapłodnienie - zasadniczo było przez respondentów odbierane pozytywnie najpierw w przypadku małżeństw, potem również związków nieformalnych, tym bardziej, że dla wielu osób wydaje się ono jedyną nadzieją na biologiczne rodzicielstwo. W przypadku małżeństw niemogących mieć dzieci również respondenci deklarujący się jako bardziej religijni, byli dość pozytywnie nastawieni do sztucznego zapłodnienia (w niektórych badaniach ponad połowa $z$ nich). Nieco inaczej przedstawia się problem sztucznego zapłodnienia w przypadku samotnych kobiet, choć i tu odsetek respondentów aprobujących to rozwiązanie relatywnie nie był niski. Wydaje się jednak, że przyczyn mniejszego poparcia można upatrywać nie tyle w sposobie poczęcia dziecka (a więc oddzieleniu prokreacji od aktu małżeńskiego), co raczej w przyszłym samotnym rodzicielstwie.

Kolejny problem dotyczy dość wysokiego poparcia, jakie wyrażali: 1) respondenci przeciętnie religijni dla in vitro dla małżeństw niemogących mieć dzieci oraz dla związków nieformalnych, problemu embrionów nadliczbowych oraz dla możliwości skorzystania z procedury sztucznego zapłodnienia przez siebie, 2) respondenci bardziej religijni dla in vitro dla małżeństw niemogących mieć dzieci. W nawiązaniu do tych wyników należy postawić pytanie o skuteczność przekazu prezentowanej przez Kościół argumentacji dotyczącej sztucznego zapłodnienia, a także o to, na ile odbiorcy w ogóle rozumieją argumentację dotyczącą nierozerwalności aspektu prokreacyjnego i więziotwórczego aktu małżeńskiego. Za znamienną należy uznać tu opinię zawartą $\mathrm{w}$ jednym z raportów CBOS, która odnosi się wprawdzie do ogółu społeczeństwa, niemniej wspomniane kategorie również są jego częścią: „można odnieść wrażenie, że wysuwane przez Kościół zastrzeżenia moralne dotyczące stosowania tej techniki, odnoszące się przede wszystkim do tworzenia nadliczbowych zarodków i instrumentalizacji ludzkiego życia, wydają się większości osób mało zrozumiałe i nieistotne, szczególnie jeśli stoją one na przeszkodzie realizacji takiej wartości, jaką jest posiadanie dziecka. W efekcie większość społeczeństwa nie zgadza się z nauczaniem Kościoła katolickiego w kwestii zapłodnienia in vitro, nie uznaje też za grzech przeprowadzania takich zabiegów, korzystania z nich czy też popierania prawa, które je dopuszcza" (CBOS 2010b, 11).

\footnotetext{
${ }^{17}$ Niniejszy wniosek jest wynikiem dyskusji z prof. Dorotą Kornas-Bielą.
} 
Szczególną uwagę należy zwrócić na kwestię zarodków nadliczbowych, którą na razie można uznać w kontekście sztucznego zapłodnienia za jedną z trudniejszych do przyjęcia dla osób religijnych (oprócz in vitro dla samotnych kobiet). Niemniej, jeśli (a pewnie bardziej „kiedy” niż ,jeśli”) rozwój medycyny pozwoli na redukcję do jednego liczby zarodków potrzebnych do skutecznego przeprowadzenia procedury sztucznego zapłodnienia i wyeliminowany zostanie problem tworzenia większej ilości zarodków i zamrażania tych, które nie zostały wykorzystane, to wówczas (zważając na odpowiedzi osób religijnych na inne pytania związane $\mathrm{z}$ in vitro) dużo trudniej będzie przekonać również osoby religijne (o ogóle nie wspominając) do innych argumentów, które powodują sprzeciw Kościoła wobec zapłodnienia in vitro. Dlatego konieczne są badania jakościowe, dzięki którym będzie można poznać motywacje respondentów religijnych (a szczególnie tych bardziej religijnych) do udzielania odpowiedzi sprzecznych z nauczaniem Kościoła - czy jest to kwestia niezrozumienia, czy jednak już świadomego stanięcia w opozycji do nauczania Kościoła.

Można zresztą powiedzieć, że konieczność zbadania motywacji dotyczy w ogóle ingerencji w naturę, w naturalny przebieg aktu płciowego, niezależnie czy celem takich ingerencji jest prokreacja oderwana od aktu płciowego (in vitro), czy wprost przeciwnie - akt oderwany od prokreacji (antykoncepcja). Problem wydaje się o tyle istotny, że respondenci widzą, że w innych przypadkach, gdzie występują ingerencje $\mathrm{w}$ naturę, nie są one sprzeczne $\mathrm{z}$ nauczaniem Kościoła (jak np. w przypadku przeszczepów).

Kolejną kwestią, nad którą trzeba się zatrzymać, jest niejednoznaczny (przynajmniej od przełomu wieków) stosunek do eutanazji, gdzie przewaga aprobaty bądź dezaprobaty zmieniała się z badania na badanie, a biorąc pod uwagę możliwość różnego sformułowania pytań dotyczących tej samej kwestii - to również $\mathrm{w}$ ramach jednego badania. $\mathrm{Z}$ kolei biorąc pod uwagę pytania oparte na skali - przeważały wprawdzie odpowiedzi wyrażające dezaprobatę, jednakże w niektórych badaniach taki sam wynik osiągały odpowiedzi wskazujące na aprobatę (dodatkowo ok. 1/3 respondentów udzielało odpowiedzi ambiwalentnej, zaznaczając środek skali lub odpowiedź ,trudno powiedzieć"). O ile zatem w przypadku aborcji, in vitro i antykoncepcji respondenci opowiadali się mniej lub bardziej wyraźnie za ich dopuszczalnością (bądź w niektórych przypadkach - przeciw), o tyle w przypadku eutanazji brak jednoznacznych wyników. Można w tym miejscu postawić pytanie, czy owa niejednoznaczność opinii (lub pewien sprzeciw wobec eutanazji) nie jest związana z faktem, że o ile w przypadku aborcji, in vitro czy chociażby antykoncepcji respondenci nie są bezpośrednimi ich uczestnikami bądź nie są wystawieni na bezpośrednie następstwa tych działań (albo jeśli są, to niekoniecznie uświadamiają sobie ich potencjalne skutki), o tyle w przypadku euta- 
nazji - jak można sądzić - są w stanie odnieść ją do samych siebie. Znaczące wydają się tu wyniki z 4 badań z lat 1999-2009 z uwzględnieniem podziału respondentów na grupy wiekowe - widać bowiem, że starsi respondenci wyraźnie mniej skłonni byli zaakceptować eutanazję niż młodsi - szczególnie porównując grupy wiekowe 18-24 lata (akceptacja dla eutanazji w przedziale $41-51 \%$ ) i 65 lat i więcej (akceptacja w przedziale 12-27\%). Wyniki te mogą sugerować obawę starszych o swój los, a w przypadku młodszych - myśl o rozwiązaniu problemu opieki nad starszym pokoleniem (również jeśli mowa jest o sytuacji, kiedy eutanazja przeprowadzana jest na wyraźne życzenie samego zainteresowanego), niemniej tutaj również konieczne jest rozpoznanie motywacji respondentów.

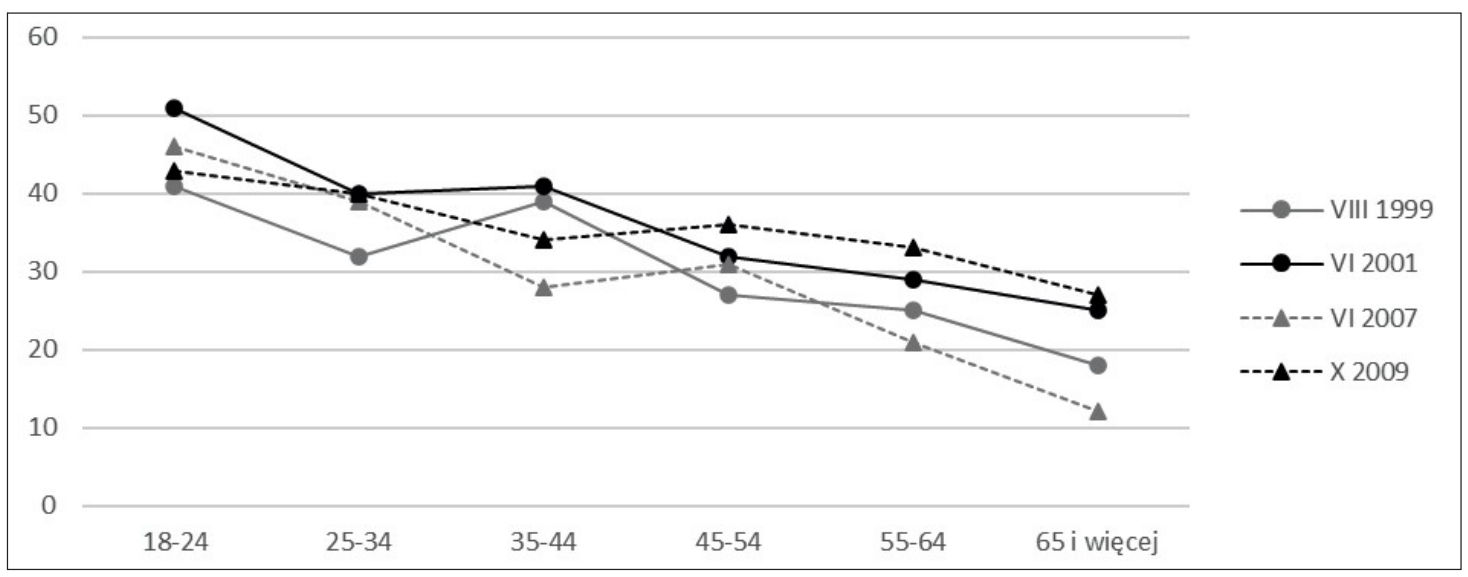

Wykres 27. Dopuszczalność eutanazji a w wiek respondentów (w procentach) ${ }^{18}$

Można wreszcie postawić pytanie o to, czy zaprezentowane powyżej wyniki - zwłaszcza jeśli chodzi o osoby deklarujące się jako przeciętnie i bardziej religijne - należy uznać za zaskakujące. Wydaje się, że mimo wszystko jednak nie. Jeszcze w latach 80. ubiegłego wieku Władysław Piwowarski w rozmowie z Józefem Wołkowskim oceniając postawy ówczesnych Polaków w zakresie wiary, określił ich jako w dużym stopniu ,nieświadomych heretyków", uznając za ortodoksyjnych najwyżej 1/3 katolików (Blaski i cienie polskiej religijności, 1984, 31). Odnosząc się do owych 2/3 określonych mianem „nieświadomych heretyków”, zaznaczył, że „odnosi się to tylko do wiary religijnej. Znacznie gorzej natomiast przedstawia się sprawa moralności religijnej. Zarówno zresztą kwestionowanie dogmatów wiary, jak i kwestionowanie

\footnotetext{
${ }^{18}$ Zestawienie badań - por. tabela 4 w aneksie.
} 
religii w życiu codziennym w dużym stopniu zaczyna się właśnie od moralności, zwłaszcza zaś moralności małżeńskiej i rodzinnej. Moralność ta zdaje się bardziej kształtować pod wpływem pewnych wartości funkcjonujących w kulturze, aniżeli pod wpływem instytucji i wierzeń religijnych" (Blaski i cienie polskiej religijności, 1984, 31). Opinia ta, wyrażona niemalże cztery dekady temu, w sytuacji dużo mniejszego dostępu do różnych źródeł wiedzy oraz konkurencyjnych wzorców kulturowych, wydaje się ciągle aktualna. Warto jednak rozważyć, czy w obliczu szerokich możliwości dostępu do informacji (w tym o nauczaniu Kościoła), jak również w obliczu bogactwa konkurencyjnych wzorców i wartości, ciągle można mówić w zakresie nauki moralnej Kościoła o heretykach nieświadomych, czy może trzeba uznać, że kwestionują ją coraz bardziej świadomie.

\section{Podsumowanie}

W nawiązaniu do zaprezentowanych wyników badań można na koniec postawić pytanie o kierunek, w jakim będą się dokonywać zmiany stanowiska Polaków odnośnie do analizowanych zjawisk. Niewątpliwie kwestia ta uzależniona jest od wielu czynników, sytuacji, zdarzeń, które w tym momencie trudno przewidzieć. Jednakże, biorąc pod uwagę możliwe odwrócenie tendencji, jakie (być może) widoczne jest w przypadku aborcji, można spodziewać się bardziej liberalnego nastawienia respondentów do analizowanych tutaj kwestii (pomimo, że w przypadku części z nich brakuje badań z ostatnich lat). Warto jednak w tym kontekście przyjrzeć się wynikom badań (zwłaszcza z ostatnich kilku lat) dotyczącym poglądów politycznych młodych ludzi w wieku 18-24 lat (CBOS 2021), a więc tych, którzy podejmują lub wkrótce będą podejmować (lub nie będą) zadania związane z prokreacją, a nieco później np. z opieką nad starszymi rodzicami. Pomijając kwestie ogólnej polaryzacji stanowisk młodych ludzi (wyraźne zmniejszenie się odsetków osób deklarujących poglądy centrowe oraz takich, które nie potrafią się określić), szczególną uwagę trzeba zwrócić na deklaracje kobiet. O ile poglądy prawicowe (które wcale nie są jednoznaczne z akceptacją nauczania Kościoła) deklarowało w tym okresie od $14 \%$ do $21 \%$ respondentek (najmniej w roku 2019), o tyle jeśli chodzi o poglądy lewicowe, to przez cztery lata między rokiem 2015 i 2019 odsetek respondentek deklarujących takie poglądy podwoił się (wzrost z 9\% na 19\%). Na kolejne podwojenie wystarczył rok, bowiem w badaniach z roku 2020 deklarację poglądów lewicowych złożyło już $40 \%$ respondentek (a w miastach powyżej 100 tys. mieszkańców - 54\%), co więcej na przestrzeni ostatnich 30 lat jest to najwyższy wynik (jedynie w roku 2015 tyle samo mężczyzn deklarowało poglądy prawicowe; największy dotychczas odsetek respondentek o poglądach 
lewicowych odnotowano w roku 1990 - nieco ponad 30\%, w kolejnych latach maksymalny wynik sięgał $25 \%$, a minimalny - poniżej $10 \%$ ). Biorąc pod uwagę kontekst (spory o aborcję, ,strajk kobiet”, ale również dyskusje o in vitro), w jakim nastąpił ów znaczący wzrost poziomu deklaracji poglądów lewicowych wśród młodych kobiet, należy sądzić, że w tych deklaracjach lewicowości zdecydowanie bardziej chodzi o wymiar światopoglądowy niż ekonomiczno-gospodarczy. Należy się zatem spodziewać, że tym bardziej przełoży się to w kolejnych odsłonach badań na opinie o analizowanych tu zjawiskach jako wzrost odsetka opinii sprzecznych z nauczaniem Kościoła (choć na razie trudno określić skalę tej zmiany). Co więcej - należy się spodziewać, że taka sytuacja będzie miała coraz większe przełożenie również na praktykę (w przypadku niektórych kwestii już ma - zwłaszcza jeśli chodzi o antykoncepcję i in vitro, w przypadku innych jest to zapewne kwestia czasu).

Tak jak wspomniano wcześniej, powyższe wnioski trudno uznać za nowatorskie, jednak odnosząc się do przedstawionych wyników - zwłaszcza w przypadku osób określających się jako przynajmniej przeciętnie religijne (z których tak wiele jednak dopuszcza przynajmniej wybrane aspekty zjawisk negatywnie ocenianych przez Kościół) - muszą one stać się przedmiotem pilnych refleksji, dyskusji i dalszych analiz, szczególnie jeśli chodzi o skuteczność i zrozumiałość nauczania Kościoła oraz formę jego przekazu. O ile bowiem kształtowanie przekonań ogółu Polaków będzie coraz trudniejsze (o ile w ogóle możliwe), o tyle z punktu widzenia Kościoła zgodność przekonań osób religijnych z nauką Kościoła należy uznać za kwestię priorytetową. Jednakże aby można było zwiększyć skuteczność i jasność przekazu, konieczne jest dogłębne rozpoznanie sposobu myślenia grupy docelowej owego przekazu. W tej sytuacji - jak już wcześniej wspomniano - za absolutnie konieczne należy uznać pogłębione badania jakościowe, które pozwoliłyby na rozpoznanie motywacji, jakie kierują respondentami - zwłaszcza religijnymi - w udzielaniu odpowiedzi (a także w praktykach), które są jednak niezgodne z nauczaniem Kościoła. 


\section{Aneks}

Tabela 1. Zestawienie raportów z badaniami dotyczącymi aborcji wykorzystanych w analizie

\begin{tabular}{|l|l|l|l|l|l|}
\hline \multicolumn{1}{|c|}{$\begin{array}{c}\text { Data } \\
\text { publikacji }\end{array}$} & $\begin{array}{c}\text { Ośrodek } \\
\text { badawczy }\end{array}$ & \multicolumn{1}{|c|}{$\begin{array}{c}\text { Numer } \\
\text { komunikatu }\end{array}$} & \multicolumn{1}{|c|}{$\begin{array}{c}\text { Data } \\
\text { publikacji }\end{array}$} & $\begin{array}{c}\text { Ośrodek } \\
\text { badawczy }\end{array}$ & \multicolumn{1}{|c|}{$\begin{array}{c}\text { Numer } \\
\text { komunikatu }\end{array}$} \\
\hline XI 1992 & CBOS & BS/409/104/92 & II 2005 & CBOS & BS/37/2005 \\
\hline VII 1994 & OBOP & $43 / 94$ & XI 2006 & CBOS & BS/173/2006 \\
\hline VII 1995 & OBOP & $73 / 95$ & X 2007 & CBOS & BS/152/2007 \\
\hline III 1996 & OBOP & $32 / 96$ & VII 2010 & CBOS & BS/100/2010 \\
\hline X 1996 & CBOS & BS/152/150/96 & IX 2011 & CBOS & BS/102/2011 \\
\hline XI 1996 & CBOS & BS/176/174/96 & XII 2012 & CBOS & BS/160/2012 \\
\hline I 1997 & OBOP & $002 / 97$ & IV 2016 & CBOS & BS/51/2016 \\
\hline VII 1997 & CBOS & BS/97/97/97 & V 2016 & CBOS & BS/71/2016 \\
\hline VIII 1999 & CBOS & BS/127/99 & X 2016 & CBOS & BS/144/2016 \\
\hline XI 2002 & CBOS & BS/191/2002 & XI 2020 & CBOS & $153 / 2020$ \\
\hline IX 2003 & CBOS & BS/139/2003 & & & \\
\hline
\end{tabular}

Tabela 2. Zestawienie raportów CBOS z badaniami dotyczącymi sztucznego zapłodnienia wykorzystanych w analizie

\begin{tabular}{|l|l|l|l|}
\hline \multicolumn{1}{|c|}{ Data publikacji } & \multicolumn{1}{c|}{ Numer komunikatu } & \multicolumn{1}{|c|}{ Data publikacji } & \multicolumn{1}{c|}{ Numer komunikatu } \\
\hline IV 1995 & BS/90/76/95 & III 2009 & BS/37/2009 \\
\hline III $1997^{*}$ & BS/41/2003 & VII 2010 & BS/96/2010 \\
\hline III 2003 & BS/41/2003 & IX 2012 & BS/121/2012 \\
\hline V 2003 & BS/78/2003 & XI 2014 & $153 / 2014$ \\
\hline II 2005 & BS/37/2005 & VII 2015 & $96 / 2015$ \\
\hline I 2008 & BS/11/2008 & & \\
\hline
\end{tabular}

* Wyniki badań z roku 1997 dla „Gazety Wyborczej” zostały zawarte w raporcie z III 2003.

Tabela 3. Zestawienie raportów z badaniami dotyczącymi antykoncepcji wykorzystanych $\mathrm{w}$ analizie

\begin{tabular}{|l|l|l|l|l|l|}
\hline \multicolumn{1}{|c|}{$\begin{array}{c}\text { Data } \\
\text { publikacji }\end{array}$} & \multicolumn{1}{|c|}{$\begin{array}{c}\text { Ośrodek } \\
\text { badawczy }\end{array}$} & \multicolumn{1}{|c|}{$\begin{array}{c}\text { Numer } \\
\text { komunikatu }\end{array}$} & $\begin{array}{c}\text { Data } \\
\text { publikacji }\end{array}$ & $\begin{array}{c}\text { Ośrodek } \\
\text { badawczy }\end{array}$ & \multicolumn{1}{c|}{$\begin{array}{c}\text { Numer } \\
\text { komunikatu }\end{array}$} \\
\hline $1980^{*}$ & OBOP & K.118/97 & VIII 2008 & CBOS & BS/54/2008 \\
\hline V 1997 & OBOP & K.118/97 & III 2009 & CBOS & BS/40/2009 \\
\hline III 2003 & TNS OBOP & $020-03$ & VII 2010 & CBOS & BS/99/2010 \\
\hline VII 2005 & TNS OBOP & $044 / 05$ & VIII 2013 & CBOS & BS/111/2013 \\
\hline VIII 2005 & CBOS & BS/133/2005 & II 2014 & CBOS & $15 / 2014$ \\
\hline
\end{tabular}

* Wyniki badań z roku 1980 są zawarte w komunikacie z V 1997. 
Tabela 4. Zestawienie raportów z badaniami dotyczącymi eutanazji wykorzystanych w analizie

\begin{tabular}{|l|l|l|l|l|l|}
\hline \multicolumn{1}{|c|}{$\begin{array}{c}\text { Data } \\
\text { publikacji }\end{array}$} & $\begin{array}{c}\text { Ośrodek } \\
\text { badawczy }\end{array}$ & Numer komunikatu & $\begin{array}{c}\text { Data } \\
\text { publikacji }\end{array}$ & $\begin{array}{c}\text { Ośrodek } \\
\text { badawczy }\end{array}$ & Numer komunikatu \\
\hline $1980^{*}$ & OBOP & K.118/97 & VI 2005 & CBOS & BS/101/2005 \\
\hline $1988^{*}$ & CBOS & BS/134/99 & VIII 2005 & CBOS & BS/133/2005 \\
\hline $1993^{*}$ & OBOP & $85 / 95$ & VII 2005 & TNS OBOP & $044 / 05$ \\
\hline VIII 1995 & OBOP & $85 / 95$ & VI 2007 & CBOS & BS/93/2007 \\
\hline V 1997 & OBOP & K.118/97 & X 2009 & CBOS & BS/142/2009 \\
\hline VIII 1999 & CBOS & BS/134/99 & VII 2010 & CBOS & BS/99/2010 \\
\hline VI 2001 & CBOS & BS/48/2001 & I 2013 & CBOS & BS/3/2013 \\
\hline III 2003 & TNS OBOP & $020-03$ & VIII 2013 & CBOS & BS/111/2013 \\
\hline
\end{tabular}

* Wyniki badań z lat 1980, 1988 i 1993 zawarte odpowiednio w komunikatach z V 1997, VIII 1999 i VIII 1995.

\author{
AROUND THE BEGINNING AND THE END OF HUMAN LIFE. \\ REFLECTION ON THE ATTITUDE OF POLES TO SELECTED \\ BIOETHICAL ISSUES FROM THE TEACHING OF THE CATHOLIC \\ CHURCH IN THE LIGHT OF SOCIAL OPINION SURVEYS
}

\title{
SUMMARY
}

The paper presented the attitude of Poles, recorded over the years, to four selected bioethical problems (abortion, in vitro fertilisation, contraception, euthanasia), to which the Catholic Church pays special attention in its teaching, and which are related to the beginning and/or end of human life.

The paper first presented the attitude of general respondents to the above mentioned issues, and then respondents declaring regular religious practices. The observation of the opinion of the latter raises the question about the effectiveness of the message of the Church's teaching on the above mentioned bioethical issues.

Keywords: social opinion surveys, abortion, in vitro, contraception, euthanasia

Słowa kluczowe: badania opinii społecznej, aborcja, in vitro, antykoncepcja, eutanazja 


\section{BIBLIOGRAFIA}

Blaski i cienie polskiej religijności. Z ks. prof. dr. Władysławem Piwowarskim rozmawia Józef Wołkowski. 1984. W: Oblicza katolicyzmu w Polsce, red. Józef Wołkowski, 9-45. Warszawa: Instytut Wydawniczy PAX.

Deneka, Alicja. 2021. Kobieta musi mieć prawo wyboru. PE przyjąt historyczna rezolucję: Dostęp do aborcji, antykoncepcji i edukacji seksualnej. Dostęp: 25.06.2021. https://www.gazetaprawna.pl/wiadomosci/swiat/artykuly/8198101,parlament-europejski-prawo-do-aborcji-prawa-kobi et-antykoncepcja-edukacja-seksualna.html.

Franciszek. 2016. Posynodalna adhortacja apostolska „Amoris laetitia”.

Gębka, Mikołaj. 2018. (Nie)dopuszczalne ograniczanie liczby potomstwa? Refleksja o aborcji w świadomości społecznej Polaków (na podstawie badań opinii publicznej), Teologia i Moralność vol. 13, nr 2 (24), 147-167. doi: 10.14746/tim.2018.24.2.8.

Jan Paweł II. 1981. Adhortacja apostolska o zadaniach rodziny chrześcijańskiej w świecie wspótczesnym ,Familiaris consortio”.

Jan Paweł II. 1994. List do rodzin „Gratissimam sane”.

Jan Paweł II. 1995. Encyklika o wartości i nienaruszalności ludzkiego życia „Evangelium vitae”.

Kongregacja Nauki Wiary. 1974. Deklaracja o sztucznym poronieniu , Quaestio de abortu procurato”. Kongregacja Nauki Wiary. 1980. Deklaracja o eutanazji „Iura et bona”.

Kongregacja Nauki Wiary. 1987. Instrukcja o szacunku dla rodzacego się życia ludzkiego i o godności jego przekazywania. Odpowiedzi na niektóre aktualne zagadnienia „,Donum vitae”.

Kościót w Polsce. Raport, red. Marcin Przeciszewski i Rafał Łączny. 2021. Warszawa: Katolicka Agencja Informacyjna. Dostęp: 30.06.2021. https://www.ekai.pl/wp-content/uploads/2021/04/ KAI_Raport_Kosciol-_w_Polsce_2021_2.pdf.

Machinek, Marian. 2011. Życie niegodne życia? Krótka historia eutanazji., Studia Warmińskie, nr 48, 325-337. Dostęp: 30.06.2021. https://bazhum.muzhp.pl/media//files/Studia_Warminskie/Studia_Warminskie-r2011-t48/Studia_Warminskie-r2011-t48-s325-337/Studia_Warminskie-r2011-t48-s325-337.pdf.

Paweł VI. 1968. Encyklika o zasadach moralnych $w$ dziedzinie przekazywania życia ludzkiego „Humanae vitae".

Rabiega, Remigiusz. 2006. Eutanazja jako problem prawny i etyczny. Prawo Kanoniczne, 59 (1), 161-178. doi: 10.21697/pk.2016.59.1.08. Dostęp: 30.06.2021. http://cejsh.icm.edu.pl/cejsh/element/bwmeta1.element.ojs-doi-10_21697_pk_2016_59_1_08.

Rp.pl. 2021. Parlament Europejski: Dostęp do aborcji jest prawem człowieka. Dostęp: 25.06.2021. https://www.rp.pl/Spor-o-aborcje/2 10629605-Parlament-Europejski-Dostep-do-aborcji-jestprawem-czlowieka.html.

Sobór Watykański II. 1965. Konstytucja duszpasterska o Kościele w świecie wspótczesnym „Gaudium et spes".

Ustawa z dnia 7 stycznia 1993 r. o planowaniu rodziny, ochronie płodu ludzkiego $i$ warunkach dopuszczalności przerywania ciąży. 1993. Dz.U. z 1993 r., nr 17, poz. 18 z późn. zm.

Zawadka, Janusz i Ryszard Balicki. 2015. Eutanazja - ,prawem do śmierci”?. Przeglad Prawa Konstytucyjnego, $\mathrm{nr} 1$ (23), 135-158. doi: 10.15804/ppk.2015.01.07. Dostęp: 30.06.2021. http://cejsh.icm.edu.pl/cejsh/element/bwmeta1.element.desklight-46442a7e-4670-4454-8ce8-267 eaec9b24a.

\section{Raporty z badań}

CBOS. 1992. Opinia spoleczna o przerywaniu ciąży. Warszawa: CBOS. BS/409/104/92.

CBOS. 1995. Dziecko „,z probówki”. Warszawa: CBOS. BS/90/76/95.

CBOS. 1996a. Nowelizacja ustawy antyaborcyjnej $i$ jej konsekwencje. Warszawa: CBOS. BS/176/174/96. 
CBOS. 1996b. Stosunek do aborcji wobec liberalizacji przepisów jej dotyczacych. Warszawa: CBOS. BS/152/150/96.

CBOS. 1997. Stosunek do aborcji po orzeczeniu Trybunatu Konstytucyjnego. Warszawa: CBOS. BS/97/97/97.

CBOS. 1999a. Młodzież i dorośli o aborcji. Warszawa: CBOS. BS/127/99.

CBOS. 1999b. Postawy wobec eutanazji. Warszawa: CBOS. BS/134/99.

CBOS. 2001. Opinie o eutanazji. Warszawa: CBOS. BS/48/2001.

CBOS. 2002. Opinie o prawie do aborcji. Warszawa: CBOS. BS/191/2002.

CBOS. 2003a. Dziecko „z probówki” - postawy wobec zapłodnienia pozaustrojowego. Warszawa: CBOS. BS/78/2003.

CBOS. 2003b. Opinie o prawnej regulacji przerywania ciaży. Warszawa: CBOS. BS/139/2003.

CBOS. 2003c. Postawy wobec klonowania. Warszawa: CBOS. BS/41/2003.

CBOS. 2005a. Aborcja. edukacja seksualna. zapłodnienie pozaustrojowe. Warszawa: CBOS. $\mathrm{BS} / 37 / 2005$.

CBOS. 2005b. Poparcie dla eutanazji a przyzwolenie na określone działania w tym zakresie. Warszawa: CBOS. BS/101/2005.

CBOS. 2005c. Wartości i normy w życiu Polaków. Warszawa: CBOS. BS/133/2005.

CBOS. 2006. Postawy wobec aborcji. Warszawa: CBOS. BS/173/2006.

CBOS. 2007a. Opinie na temat aborcji. Warszawa: CBOS. BS/152/2007.

CBOS. 2007b. Opinie o eutanazji. czyli pomocy w umieraniu. Warszawa: CBOS. BS/93/2007.

CBOS. 2008a. Kontrowersje wokót różnych zjawisk dotyczących życia matżeńskiego i rodzinnego. Warszawa: CBOS. BS/54/2008.

CBOS. 2008b. Opinie o dopuszczalności stosowania zapłodnienia pozaustrojowego. Warszawa: CBOS. BS/11/2008.

CBOS. 2009a. Akceptacja stosowania zapłodnienia in vitro. Warszawa: CBOS. BS/37/2009.

CBOS. 2009b. Moralność Polaków po dwudziestu latach przemian. Warszawa: CBOS. BS/40/2009.

CBOS. 2009c. Opinia spoteczna o eutanazji. Warszawa: CBOS. BS/142/2009.

CBOS. 2010a. Co jest ważne, co można, a czego nie wolno - normy i wartości w życiu Polaków. Warszawa: CBOS. BS/99/2010.

CBOS. 2010b. Etyczne aspekty zapłodnienia in vitro. Warszawa: CBOS. BS/96/2010.

CBOS. 2010c. Opinie na temat dopuszczalności aborcji. Warszawa: CBOS. BS/100/2010.

CBOS. 2011. Opinie o prawnej dopuszczalności i regulacji aborcji. Warszawa: CBOS. BS/102/2011.

CBOS. 2012a. Opinie o prawie aborcyjnym. Warszawa: CBOS. BS/160/2012.

CBOS. 2012b. Postawy wobec stosowania zaptodnienia in vitro. Warszawa: CBOS. BS/121/2012.

CBOS. 2013a. Wartości i normy. Warszawa: CBOS. BS/111/2013.

CBOS. 2013b. Zaniechanie uporczywej terapii a eutanazja. Warszawa: CBOS. BS/3/2013.

CBOS. 2014a. Prawo a moralność - opinie o zachowaniach kontrowersyjnych. Warszawa: CBOS. $153 / 2014$.

CBOS. 2014b. Religijność a zasady moralne. Warszawa: CBOS. 15/2014.

CBOS. 2015a. Oczekiwane zmiany w nauczaniu Kościoła. Warszawa: CBOS. 32/2015.

CBOS. 2015b. Opinie o dopuszczalności stosowania zaptodnienia in vitro. Warszawa: CBOS. 96/2015.

CBOS. 2016a. Dopuszczalność aborcji w różnych sytuacjach. Warszawa: CBOS. BS/71/2016.

CBOS. 2016b. Jakiego prawa aborcyjnego oczekuja Polacy. Warszawa: CBOS. BS/144/2016.

CBOS. 2016c. Opinie o dopuszczalności aborcji. Warszawa: CBOS. BS/51/2016.

CBOS. 2020. O dopuszczalności przerywania ciaży i protestach po wyroku Trybunału Konstytucyjnego. Warszawa: CBOS. 153/2020.

CBOS. 2021. Poglady polityczne młodych Polaków a płeć i miejsce zamieszkania. Warszawa: CBOS. 28/2021.

OBOP. 1994. Polacy o prawnym zakazie przerywania ciązy. Warszawa: Telewizja Polska S.A. OBOP. 43/94. 
OBOP. 1995a. Jakie zachowania potepiamy. Warszawa: OBOP. 85/95.

OBOP. 1995b. Polacy o aborcji. Warszawa: Telewizja Polska S.A. OBOP. 85/95.

OBOP. 1995b. Polacy o aborcji. Warszawa: Telewizja Polska S.A. OBOP. 73/95.

OBOP. 1996. Opinie o dopuszczalności aborcji. Warszawa: OBOP. 32/96.

OBOP. 1997a. Czy przerywanie ciaży powinno być dozwolone, czy nie?. Warszawa: OBOP. 002/97. OBOP. 1997b. Opinie Polaków o różnych zachowaniach. Warszawa: OBOP. K.118/97.

TNS OBOP. 2003. Dokad zmierza świat. Warszawa: TNS OBOP. 020-03.

TNS OBOP. 2005. Nowe się cofa. Warszawa: TNS OBOP. 044/05.

Mikołaj Gębka - doktor, socjolog, adiunkt na Wydziale Teologicznym UAM, absolwent Podyplomowego Studium Rodziny na WT UAM, zainteresowania naukowe: socjologia rodziny. 